\title{
GUERRA Y PROPAGANDA EN EL REINADO DE FELIPE V
}

\section{War and Propaganda in the Reign of Philip $V$}

\author{
Cristina BORREGUERO BELTRÁN \\ Universidad de Burgos \\ cbeltran@ubu.es
}

Fecha de recepción: 15/04/2020

Fecha de aceptación definitiva: 12/07/2020

RESUMEN: Este artículo trata de ofrecer un análisis del alcance propagandístico de las guerras durante el reinado de Felipe V. No solo la contienda sucesoria a principios de siglo hizo emerger una penetrante y virulenta propaganda debido a su vertiente civil en suelo peninsular, también las guerras de Italia y las expediciones al norte de África, que buscaron la recuperación de territorios muy estimados por la Monarquía, tuvieron particular influencia en la opinión pública española y europea. Muy significativos fueron los sentimientos anglófobos y antihispanos suscitados por la guerra de la Oreja de Jenkins o guerra del Asiento.

Palabras clave: guerra; propaganda; publicística; monarquía borbónica; victorias militares; derrotas.

ABSTRACT: This article tries to offer an analysis of the propagandistic scope of the wars during the reign of Philip V. Not only the Spanish War of Succession at the beginning of the century gave rise to a penetrating and virulent propaganda due to its civil aspect on peninsular soil, also the wars in Italy and the expeditions to North Africa, which sought the recovery of territories highly esteemed by the Monarchy, had a particular influence in Spanish and European public opinion. Very significant were the Anglophobic and anti-Hispanic feelings raised by the War Jenkins' Ear or "guerra del Asiento". 
Key words: war; propaganda; public opinion; Borbon monarchy; military victories; defeats.

\section{INTRODUCCIÓN}

Atribuida por algunos a Winston Churchill, todavía hoy no se conoce a ciencia cierta quién dijo por primera vez la famosa y conocida frase «la historia la escriben los vencedores", pues existen versiones más tempranas en francés, italiano y alemán. Debido a su concisión, el adagio puede interpretarse de distintas formas; una de ellas vendría a significar que la propaganda de los triunfadores es la principal fuente de la historia o la que ha prevalecido. Sin embargo, la expresión ha desarrollado una nueva fórmula con no menos fortuna: «la historia la escriben los vencedores, pero el paso del tiempo también da voz a los vencidos", proponiendo una versión posterior de los hechos que, protagonizada por los derrotados, vendría a equilibrar la balanza.

Sea lo que fuere, si algo caracteriza por definición a la propaganda es la referencia a sus promotores, que no siempre fueron los victoriosos, sino también aquellos que deseaban alcanzar el triunfo. Por ello, la propaganda de guerra puede incluir tanto las campañas de preparación de la opinión pública llevadas a cabo por los gobiernos para justificar sus posiciones, reclutar hombres y prevenir contra sus enemigos, como la publicística generada por las victorias, los generales triunfadores, las ganancias territoriales.

Ciertamente la propaganda militar, muy unida a la propaganda política, tuvo un desarrollo sin parangón en el siglo XVIII, propiciada por su uso y desarrollo desde muchos siglos antes. No deja de asombrar, por ejemplo, la actividad propagandística sin precedentes que trajo consigo la victoria de Carlos V en la batalla de Mühlberg (1547). Una empresa «multimedia», como la llamó Elliot y Kagan, que además de crear el mito del triunfo del emperador sobre el protestantismo, se perpetuó incluso después de su muerte ${ }^{1}$.

Los estudios sobre propaganda en determinados periodos de la historia analizan, entre otros temas, el contexto de la época, las campañas propagandísticas organizadas mediante los servicios encargados de su gestión, las estrategias, los medios y canales más utilizados en cada periodo, así como los mensajes difundidos y su tipología. Sin olvidar que muchos escritores y artistas de todos los tiempos pusieron su talento al servicio de la propaganda de sus gobiernos, en general, y de sus propios sentimientos, en particular. Pero hubo también una publicística que al calor de los acontecimientos surgió instigada y/o espontáneamente transmitiendo convicciones, juicios, creencias, opiniones, ideas, sentimientos, lamentos

1. Marino, Nancy F. "The "Romance de Carlos V" and the Emperor's Imperial propaganda machine». Caliope, 2014, 19, 2, pp. 35-49. 
y acusaciones de toda índole. Aunque en este artículo no se acomete un estudio pormenorizado del nacimiento y desarrollo de la opinión pública en España, se asiste indirectamente a su desenvolvimiento. Indudablemente, la propaganda de guerra contribuyó a crear un estado de opinión que fue desarrollándose progresivamente usando fuentes periodísticas, literarias, artísticas, etc., dirigidas a un público que se agrupaba en centros de opinión: cafés, tertulias, teatros, etc., alimentando la discrepancia y la polémica, especialmente frente a la política de censura tras las derrotas o desastres militares.

Para la Época Moderna, los trabajos sobre la propaganda de guerra se han centrado en el análisis de los diferentes mecanismos y procesos de comunicación social utilizados por el poder: desde las tácticas de influencia en la opinión pública, hasta las estrategias de justificación de la guerra como "causa justa» o «legítima defensa", la habilidad para comprar voluntades y mantener el control e, incluso, la vigilancia de las informaciones en circulación.

En el siglo XVIII, las campañas propagandísticas de Felipe V emplearon diversos instrumentos o canales al servicio del poder. El discurso de carácter oficial se plasmó en reales órdenes dirigidas a todos los reinos y en manifiestos o proclamas remitidas a las cortes europeas; en ellas se justificaba la intervención en la guerra en defensa propia o de la Corona. También resultaron útiles las memorias, apologías, crónicas y ensayos de una pléyade de escritores que apoyaban el discurso de carácter oficial.

Otra estrategia fue la exaltación de las victorias militares convirtiéndolas en grandes triunfos de la Monarquía, incluso en los casos de resultado incierto. La divulgación de estas victorias se llevó a cabo a través de las gacetas oficiales y las relaciones de sucesos, sin olvidar las celebraciones públicas en las ciudades de la Monarquía y la literatura afecta al poder.

No menos efectiva fue la habilidad de la Monarquía borbónica para encontrar los apoyos a su causa por medio de gestos de generosidad o benignidad como el reparto de mercedes, regalos, víveres e, incluso, indultos para los prisioneros y disidentes, formando redes clientelares y logrando la adhesión del pueblo.

La propaganda de guerra absorbió todos los canales que encontró a su alcance: desde la prensa escrita, los géneros literarios, los decretos legislativos, las cartas y memoriales, hasta la pintura, el grabado, las estampas, los tapices, los frescos, las monedas y medallas conmemorativas, etc., sin olvidar los sermones, homilías, arengas, letrillas y versos que se recitaban en público. Todo fue poco en el estado de guerra casi continuo de la primera mitad del siglo XVIII. El largo reinado de Felipe V se inició con una guerra civil en territorio peninsular, continuó con diversas contiendas en el Mediterráneo, para restaurar su influencia en aquel teatro de operaciones, y con una grave afrenta en el Atlántico de un enemigo naval muy poderoso. Cuando el rey murió en 1746, España seguía embarcada en la guerra de Sucesión de Austria hasta su término en 1748. 


\section{La VIRULENTA PROPAGANDA EN LA GUERRA DE SuCESión ESPAÑOla}

A comienzos del siglo XVIII, la guerra parecía no tener fin. Algunos observadores, lamentando su interminable duración, se remontaban incluso a la guerra de Flandes, porque desde aquellas fechas

Habiendo pasado ahora ciento cincuenta años con poca diferencia, en que intervinieron casi continuas Guerras, con tanto derramamiento de sangre Christiana, que quedó Flandes con el epitecto funesto de Sepulcro de los Españoles y con tan exorbitantes gastos que pudiera España como dijera bien un Discreto haber comprado otro Flandes de Plata ${ }^{2}$.

El carácter civil e internacional de la guerra de Sucesión española facilitó que se convirtiera en un laboratorio propagandístico que incrementó exponencialmente el género de la publicística. Su producción y difusión alcanzaron proporciones inéditas debido, en gran parte, al aumento de lectores, a la multiplicación del número de gacetas y periódicos y a su progresiva regularidad.

La propaganda en la guerra de Sucesión ha desarrollado una línea de investigación muy prolífica, con trabajos pioneros y de referencia de María Teresa López Picazo $^{3}$ y de Teófanes Egido ${ }^{4}$. Años más tarde aparecieron las publicaciones de David González Cruz que mostraron las líneas de comunicación de la propaganda entre la península ibérica y América o las de Marta Riess, centradas en la propaganda desde el púlpito durante la guerra de Sucesión española5. Debido a la rica documentación generada por la política y la guerra de Sucesión, se han multiplicado los estudios en diversas direcciones y temáticas ${ }^{6}$.

2. IbáÑez DE la Riva, Antonio. Demostración legal y política para el desengaño de la plebe, mandada publicar por Excmo. Sr. Arzobispo de Zaragoza para la dirección de los confesores de su Diócesis en las materias ocurrentes y desengaño de sus Súbditos y exhortarlos a dar repulsa a perjudiciales doctrinas y preservarlos de la introducción de los falsos dogmas de los Herejes. Madrid, ca. 1705 o 1706, por Antonio González de Reyes, 16 pp.

3. PÉrez Picazo, M. Teresa. La publicística española en la Guerra de Sucesión. Madrid: Consejo Superior de Investigaciones Científicas, 1966.

4. EGIDO LóPEZ, Teófanes. Opinión pública y oposición al poder en la España del siglo XVIII (1713-1759). Valladolid: Secretariado de Publicaciones e Intercambio Editorial, 2002.

5. GonzÁlez Cruz, David. Propaganda e información en tiempos de guerra: España y América (1700-1714). Madrid: Sílex, 2009. GonZÁlez CruZ, David. "Propaganda y fuentes de información en la prensa periódica de la América Hispana durante las guerras del siglo XVIII. Obradoiro de Historia Moderna, 2011, n. ${ }^{\circ}$ 20, pp. 355-384. Riess, Marta. Das wort von der Kanzel. Kirchliche Propaganda während des Spanischen Erbfolgekrieges. Sarrebruck: VDM-Verlag Dr. Müller, 2008.

6. Algunos trabajos son los de López-Cordón, M. Victoria. "La instauración de una dinastía: propaganda, poder y familia en época de los primeros Borbones». En La Real Biblioteca Pública, 1711-1760, de Felipe V a Fernando VI. Madrid: Biblioteca Nacional de Madrid, 2004, pp. 17-32. BouZA, Fernando. "Sin armas de noticias. Medios de cultura escrita, público y poder monárquico a comienzos del siglo XVIII. En La Real Biblioteca Pública, 1711-1760, de Felipe V a Fernando VI. Madrid: Biblioteca Nacional de Madrid, 2004, pp. 33-47. EgIDo LóPEZ, Teófanes. «La otra prensa del Antiguo Régimen y la oposición al poder». En Del Periódico a la Sociedad de Información, vol. I. Madrid: Sociedad Estatal 
Los dos pretendientes a la Corona utilizaron, en primer lugar, la prensa en favor de los objetivos políticos de cada uno de ellos. Además de las publicaciones oficiales -la Gaceta de Madrid en favor de Felipe V y la Gazeta de Barcelona en apoyo del archiduque Carlos- ${ }^{7}$ irrumpieron otros periódicos y multitud de impresos borbónicos y austracistas. Por ejemplo, la Gazeta de Murcia, que apareció el 10 de agosto de 1706, desempeñó una doble función: la propagandística, en defensa de la causa de los Borbones, y la informativa, cubriendo la falta de noticias en una región aislada por el conflicto ${ }^{8}$. Junto a los canales escritos, los contendientes se sirvieron también de todo tipo de imágenes -pinturas, esculturas, grabados, medallas conmemorativas, etc.- que, unido a la predicación y la arenga, se mostraron muy eficaces.

Tanto borbones como austracistas pusieron en circulación numerosos impresos y panfletos. Aquellos "papeles echadizos» se distribuían fácilmente por la calle al ser muy asequibles económicamente, por lo que tuvieron gran influencia en la población. Los destinatarios, clasificados por sus «luces», eran hábilmente captados por los métodos propagandísticos de la época:

Todos los cuerdos, prudentes y advertidos han hecho, y hacen de semejantes "papeles echadizos» el desprecio que se merecen, contentándose con haber dado a alguno de ellos cabal y eficaz respuesta. Pero como los enemigos tiran con ellos a captar la benevolencia de los vulgares, (que son los más) insisten siempre en multiplicarlos, introducirlos, y derramarlos cautamente por medio de astutos Emisarios?

La osadía de los papeles austracistas azuzaba el ingenio del bando borbónico para contrarrestar las hojas del enemigo con otros impresos que, dejando a un lado cultismos y latinismos, se dirigieran con sentido claro y llano a la gente del común.

Y por lo sucedido en algunas partes, se deja bastantemente entender, han hecho sobrada impresión en muchos Pueblos y personas. Por lo cual parece preciso tener que dar a los indoctos y plebeyos un breve claro y eficaz desengaño, prescindiendo de citas, textos y latines ${ }^{10}$.

España Nuevo Milenio, 2002, pp. 93-110. BORREguero Beltrán, C. «Imagen y propaganda de guerra en el conflicto sucesorio (1700-1713)». Manuscrits, 2003, 21, pp. 95-132. 2010.

7. Vid. Albareda, Joaquim. La guerra de Sucesión de España, 1700-1714. Barcelona: Crítica,

8. Díez Revenga, Francisco Javier. "La Gazeta de Murcia (1706): un periódico murciano de la Guerra de Sucesión». En Luis Belluga y Moncada: la dignidad de la púrpura. Murcia: Fundación CajaMurcia, 2006, pp. 203-219.

9. IBÁÑ̃E DE LA RIVA, Antonio. Demostración legal y política para el desengaño de la plebe, mandada publicar por Excmo. Sr. Arzobispo de Zaragoza para la dirección de los confesores de su Diócesis en las materias ocurrentes y desengaño de sus Súbditos y exhortarlos a dar repulsa a perjudiciales doctrinas y preservarlos de la introducción de los falsos dogmas de los Herejes. Madrid, 1705 o 1706, 16 pp., p. 2.

10. Ibid. 
En este "combate de pluma» intervinieron escritores y filósofos como los británicos Daniel Defoe ${ }^{11}$ y Jonathan Swift ${ }^{12}$, que estuvieron al servicio del partido «tory» e intervinieron para que Inglaterra saliera del conflicto y pactara con Francia; el alemán Leibniz, que escribió a favor de la causa austracista, y el joven Voltaire, convertido en un consumado maestro de la propaganda ${ }^{13}$.

Entre las ideas austracistas más difundidas destacaba la acusación hacia los Borbones de haber introducido el "fuego de la guerra» en el «corazón» de España con el fin de debilitar y aniquilar sus fuerzas. A las recriminaciones se unió la promesa de trasladar las operaciones militares a la vecina Francia para que sus habitantes padeciesen los daños y perjuicios que soportaban los españoles. A esta sugerente oferta activadora de sentimientos francófobos, se añadió la propuesta de recuperar aquellos territorios usurpados en el siglo XVII por la Monarquía francesa, que continuaban siendo añorados en el imaginario colectivo ${ }^{14}$. Pero no solo eso, en 1710, tras su victoria en Zaragoza, el archiduque proclamó la derogación de los Decretos de Nueva Planta que Felipe V había impuesto en 1707 y, por tanto, el retorno al régimen foral tradicional del reino.

Para los partidarios de Felipe V, aquellas promesas austracistas «inficionaban» y «sedicionaban» los ánimos en la España del primer Borbón:

Muchos días ha, que para efecto de sedicionar los ánimos de los Vasallos del Rey nuestro Señor Phelipe V (que dios Guarde y prospere) se empezaron a introducir por parte de los enemigos, varios papeles en los que se proponían algunas razones aparentes (que sólidas no es fácil) acerca del pretenso derecho de el Señor Archiduque a la Corona de España, añadiendo, para más obligar, algunos ofrecimientos, como eximir de tributos y otros a este tenor, de quienes por impracticable, se puede

11. Sobre Daniel Defoe, vid. LóPEz CAMPILlo, Rosa. Imagen y propaganda política en la guerra de Sucesión Española: Daniel Defoe al servicio del gobierno de Ana Estuardo. Madrid: Sílex, 2014. LÓPEZ CAmpIlLo, Rosa. "Daniel Defoe, propagandista político al servicio de los intereses comerciales británicos durante la guerra de Sucesión Española (1702-1714)». En La guerra de Sucesión Española y la opinión pública bispano-británica. Madrid: Sílex, 2014, pp. 31-54.

12. Jonathan Swift, quizá el mejor escritor satírico de las letras angloirlandesas, conocido por sus Viajes de Gulliver, escribió un panfleto titulado La conducta de los aliados, 1711, un alegato en el que sostenía que la participación de Inglaterra en la guerra de Sucesión era una sangría para el país. El panfleto tuvo efectos inmediatos en la posición de Inglaterra en la guerra de Sucesión que dejó de apoyar a los austracistas.

13. "Voltaire fue un maestro de la propaganda por su habilidad en montar una campaña. Cada vez que se le ofrecía la ocasión, bajo la apariencia de un combate por la justicia y la libertad, organizaba un vasto dispositivo propagandístico». Ellul, Jacques. Historia de la propaganda. París: Presses Universitaires de France, 1967, p. 100.

14. GonZÁlez CruZ, David. "Espacios y territorio en la propaganda y en los discursos durante los conflictos bélicos: la Guerra de Sucesión en España y América». e-Spania. Revue interdisciplinaire d'études hispaniques médiévales et modernes. [En ligne], 14, mis en ligne le 16 janvier 2013, 2012. 
decir lo que el Poeta "Pollicitis dives quilibet esse potest» (Cualquier persona puede ser rica en promesas) ${ }^{15}$.

La propaganda borbónica centró sus mensajes en contraponer la actuación de los territorios peninsulares -divididos y enfrentados en una guerra civil-, algunos de los cuales solo merecían sospecha y prevención. En ese sentido, el memorial escrito por Alonso Fernando Gutiérrez alertó de la amenaza que Portugal y Cataluña, pueblos invariablemente impacientes y descontentos con el gobierno, habían supuesto para España:

Qualquiera que piense entrarnos la espada hasta la guarnición, ya sabe que tiene abiertas dos puertas en España: una por Oriental, que es Cataluña, otra por Occidente, que es Portugal; porque estos dos Pueblos impacientes siempre, y descontentos con el gobierno presente, a qualquiera, que passe por el Mar, llamarán para que entre a ayudarlos contra el Príncipe. Nadie será Rey seguro de España, mientras no tenga bien asseguradas estas dos puertas $[\ldots]^{16}$.

Asimismo, censuró a los territorios de la Corona de Aragón por su infidelidad al juramento hecho a Felipe V, y a su población, inconstante y bulliciosa, por haberse desviado hacia el archiduque. Por el contrario, ensalzó a castellanos y extremeños por su permanente lealtad, constancia y valor:

La mayor parte de la corona de Aragón, y especialmente Valencia y Cataluña, faltando a la fe de su juramento que habían hecho a Felipe V, proclamando al archiduque, el cual pasó a aquellas provincias, y fijando su corte en Barcelona, llenó de su entusiasmo a todo aquel principado. Sus habitantes, de un corazón inconstante y bullicioso, abandonaron torpemente a Felipe. Castilla y Extremadura, por el contrario, siempre quedaron fieles, [...] y Felipe debió al valor y fidelidad de los castellanos y extremeños, el trono y la corona, que estuvo muchas veces vacilante en su cabeza ${ }^{17}$.

15. IbÁÑEz DE la Riva, Antonio. Demostración legal y política para el desengaño de la plebe, mandada publicar por Excmo. Sr. Arzobispo de Zaragoza para la dirección de los confesores de su Diócesis en las materias ocurrentes y desengaño de sus Súbditos y exhortarlos a dar repulsa a perjudiciales doctrinas y preservarlos de la introducción de los falsos dogmas de los Herejes. Madrid, ca. 1705 o 1706, por Antonio González de Reyes, 16 pp.

16. Memorial que a la ínclyta generosa nación española ofrece D. Alonso Fernando Gutierrez, cavallero de el antiguo Orden de Santiago. Lima: Imp. Alonso Fernández Fontecha, 1706, pp. 3-4. Cit. por GonzÁlez CRUZ, David. "Espacios y territorio en la propaganda y en los discursos durante los conflictos bélicos: la Guerra de Sucesión en España y América». e-Spania. Revue interdisciplinaire d'études bispaniques médiévales et modernes. [En ligne], 2012, 14, mis en ligne le 16 janvier 2013.

17. Salgado, Francisco. OSH (Monasterio de San Jerónimo de Madrid). Quinta Parte de la Historia de la Orden de San Gerónimo. Biblioteca Real del Escorial, Ms. J.1.3. Historia de los años 1674-1800. Inédita, ff. 270-271. Vid. CAMPOS Y FERNÁNDEZ DE SEvilla, Javier. "La guerra de Sucesión Española vista a través de la historia general de la orden de San Jerónimo». Cuadernos de Investigación Histórica, 2007, 24, pp. 57-98. 
Felipe V recibió un consistente soporte teórico a través de memoriales y tratados que fundamentaban sus derechos a la Corona española y un gran apoyo afectivo y emotivo. A favor de su causa, muchos papeles impresos, versos y poemas, más o menos espontáneos, le reconocían como rey aclamado y querido por el pueblo de España frente al pretendiente "Carlos III" ${ }^{18}$.

Pero los mayores ejemplos, que ha visto el mundo de amor a su Rey, y de inviolable Obediencia, y lealtad, son los que dieron el año pasado de 1705 todos los Pueblos de las Andalucías, Extremadura y Castillas, cuando el Ejército de los Aliados, aprovechándose de la distancia de nuestras Tropas, consiguieron con la violencia, que se reconociese el nombre de Carlos III hasta en la misma Corte; pero estuvo tan lejos de celebrarse esta proclamación con regocijos, ni demostraciones públicas, que reconociendo los mismos Enemigos el disgusto de los Pueblos, hicieron muchas reflexiones sobre la poca seguridad con que pisaban el terreno... ${ }^{19}$.

Los argumentos sobre su legitimidad se basaban fundamentalmente en su sangre real, en el testamento de Carlos II y en la pacífica toma de posesión de la corona el 16 de noviembre de 1700 seguida del juramento de todos los vasallos ${ }^{20}$.

EL REY NVESTRO SEÑOR DON Phelipe V (que Dios guarde) tiene derecho cierto e incontrastable a la Monarquía de España por su Sangre, por el Testamento del Señor Carlos II, por la posesión pacífica con que ocupó el Trono y por su aceptación y obediencia que le prestaron todos los Reinos ${ }^{21}$.

La campaña emotiva y sensible convirtió al monarca en un rey "deseado» por el pueblo y, muy especialmente, por la villa y corte de Madrid, donde se oyeron canciones y versos de profunda carga afectiva:

18. Un ejemplo es el de FERNÁNDEZ MONTERO, Juan. Breve relación, y compendio de los derechos... que por su sangre tiene... Felipe Quinto... à las Coronas de España, de cuyos dominios pretende despojarle el Señor Archiduque Don Carlos Francisco Joseph de Austria. 1707. BNE, R/24282(11).

19. Melo y Girón, Juan (seudónimo de Jerónimo Julián). Zelo cathólico, y español, por la Religión y por la Patria que para luz de la ignorancia, desengaño del error y enmienda de la malicia, sobre el fundamento incontrastable de la Justicia y Derecho del Rey N. S. Phelipe V (que Dios guarde) propone las indispensables obligaciones de todos los vasallos para con su Magestad... por el Doct. D. Juan Melo y Giron. En Valencia, 1708 por Antonio Bordazar; y reimpresso por mandado de los Señores de la Real Chancillería de Granada en la Imprenta de Francisco de Ochoa, 1710, pto. 50.

20. González Cruz, David. «Propaganda y estrategias de legitimación de la Sucesión en los dominios de la Monarquía Hispánica (1700-1714)». En BernARdo AREs, José Manuel (coord.). La sucesión de la Monarquía Hispánica 1665-1 725. Córdoba: Universidad de Córdoba y Cajasur, 2009, pp. 167-208.

21. Ibid. Melo y GiRón, Juan. Zelo cathólico..., op. cit. 


\begin{tabular}{l|l}
\hline Ven adorado Filipo, & Que la fábrica que hiciste \\
Credito de España, ven & Te la quieren deshacer \\
Y a la borrasca del mal & Ven, Señor, ven. \\
Se siga el Iris del bien: & Ven, no tardes Amado \\
Ven, Señor, ven & David perseguido, ven \\
& Derriba al Goliat soberbio ${ }^{22}$.
\end{tabular}

Como contrapartida, la propaganda borbónica castigó duramente la imagen del archiduque Carlos con mordaces epítetos -temerario, ambicioso, soberbio y loco- muy frecuentes en las "canciones reales»:

Un Austriaco príncipe porfía temerario al más arduo y loco empeño en perseguir al quien el Cielo dueño eligió de la Hesperia Monarquía, Icara empresa a su esperanza fía. [...]
Oh Carlos, Carlos, tu frágil ser te acuerde que quien todo lo quiere, todo pierde. La paz segura, firme y deseada es la Victoria en Lauros Inmortales, que eternicen los Triunfos Imperiales y coronen tu vida dilatada ${ }^{23}$.

La insolencia de los versos populares llegaba aún más lejos, calificando al archiduque de tirano, rebelde, ciego e intrigante, y a los catalanes de ambiciosos, traidores y locos:

\begin{tabular}{|l|l|}
\hline Díganlo los ejemplares & O si no los Catalanes \\
Castigos que recibieron & Que arrepentidos del trueco \\
Muchos tiranos rebeldes, & Se ven hoy con su ambición, \\
Que empañar quisieron ciegos & Gustando el pan de perro, \\
Los rayos del Sol de España & Perdida toda su hacienda, \\
Con diabólicos enredos. & Y perdidos ellos mesmos, \\
& Siendo su traición castigo \\
& De sus locos pensamientos ${ }^{24}$. \\
\hline
\end{tabular}

22. ANÓNImo. Clamores, lágrimas y suspiros de Madrid al Rey nuestro Señor Don Felipe Quinto (que Dios guarde felices siglos) desde cruel opresión de los enemigos (s. a., s. i.). Madrid, 1711.

23. Folleto, Canción real. El monarca perseguido por un príncipe ambicioso. Madrid, ca. 1705. http://www.memoriademadrid.es/buscador.php?accion=VerFicha\&id=31547\&num_id=18\&num_ total=89 [consultado el 12.XII.2019].

24. Astvcias de Lucyfer y desengaño de los Aliados. [s. l.], en verso. En Curioso plantel matizado de muchos floridos conceptos, que ilustran varios papeles discretos, y curiosos en verso, escritos por algunos de los ingenios grandes desta Corte en digno aplauso de nuestro Monarca y Señor Don Phelipe Quinto e Magnanimo, que Dios guarde. Madrid, 1711. "Papeles curiosos del año de 1710". Real Biblioteca de Madrid. [https://books.google.es/books/about/Astucias_de_Lucifer_y_desenga\%C3\%B1o_de_ los.html?id=UO6r7pVrZAoC\&redir_esc=y.] [consultado el 3.XII.2019]. 
Muy singular fue la utilización del género Oración, cuyas composiciones realizadas por clérigos oradores trataban de ganar voluntades hacia Felipe V, muy particularmente las de aquellos jóvenes aptos para incorporarse al ejército. Un ejemplo de esta "propaganda para el alistamiento" es el Año feliz para España ${ }^{25}$ en la que se compara la figura de Iesus, enfrentado a la malicia del diablo, con la de Felipe V, desafiado por la maldad de sus enemigos. En realidad, se buscaba captar y atraer los ánimos hacia el Borbón, "así expresando el juicio que V. S. nos manda hacer, decimos que esta Oración es muy oportuna para aficionar las voluntades a nuestro Magnánimo Philipo» ${ }^{26}$. Con todo, el Año feliz para España se convirtió en un magnífico reclamo de soldados, al argumentar que «sucederá lo que quisieren los vasallos de esta Monarquía alistándose» ${ }^{27}$.

Como en toda empresa propagandística bélica, las victorias recibieron una cobertura imponente; destacó por encima de todas la batalla de Almansa, que trajo consigo una explosión panfletaria, visual y homilética en la mayor parte de los territorios partidarios de Felipe $\mathrm{V}^{28}$. Las victorias austracistas de Zaragoza y Almenara, así como los triunfos borbónicos de Brihuega y Villaviciosa, tuvieron también gran repercusión incluso en la opinión pública británica gracias al británico George Ridpath. Desde julio de 1710 hasta principios de 1711, el periodista se dedicó a publicar el discurso "oficial» de la guerra ofrecido por la facción whig. Entre sus observaciones, volcadas en la revista política The Observator, destacaron aquellas relacionadas con las batallas que llevaron del triunfo aliado inicial a la pérdida definitiva de la guerra en territorio peninsular ${ }^{29}$.

25. SAn ANTONIO, Alejandro de O. de M. [m. 1740]. Año feliz para España en que sucederá lo que quisieren los vasallos de esta Monarquía, si alistándose debajo de la bandera del Príncipe más deseado usan las armas que rinde su coronel prisionero. Oración evangélica a la circuncisión y nombre de Jesús que en la parroquial de San Martin de Salamanca dijo el P. Fr. Alexandro de San Antonio... de Mercenarios Descalços. Salamanca; en la imprenta de Gregorio Ortiz Gallardo, 1708. BNE, Sg. R/38369(8).

26. Ibid.

27. Ibid.

28. Muy fructíferos han sido los trabajos generados por la batalla de Almansa en 2007: ALABRús Iglesias, Rosa María. "El eco de la batalla de Almansa en la publicística". Revista de Historia Moderna: Anales de la Universidad de Alicante, 2007, 25, pp. 113-128. LóPEZ-CORDón, María Victoria. "Defender a un rey, convencer a Europa: razones e imágenes de la propaganda castellana durante la contienda sucesoria». En GARCía GONZÁlEZ, Francisco (coord.). La guerra de sucesión en España y la batalla de Almansa: Europa en la encrucijada. Madrid: Sílex, 2009, pp. 285-306. SEgura Simó, Ricardo. "La pintura y el grabado en la Guerra de Sucesión: la batalla de Almansa». En SANTAMARÍA Conde, Alfonso; García-SAúco Beléndez, Luis G. y Sánchez Ferrer, José (coords.). II Congreso de Historia de Albacete. Albacete: Instituto de Estudios Albacetenses Don Juan Manuel, 2002, 3, pp. 327-341. Losa SERrano, Pedro. "La propaganda Whig sobre las batallas de Málaga, Almansa y Brihuega durante la Guerra de Sucesión". En La guerra de Sucesión Española y la opinión pública hispano-británica. Madrid: Sílex, 2014, pp. 69-98.

29. López Campillo, R. M. y Losa SERrano, P. "La propaganda política whig en la guerra de Sucesión Española. George Ridpath y las campañas peninsulares de 1710». Ensayos: Revista de la Facultad de Educación de Albacete, 2010, 25, pp. 211-232. SÁnchez RuIz, Raquel. Estrategias persuasivas y de manipulación ideológica en el discurso político: George Ridpath y la opinión pública inglesa durante 
Pero si algo cautivó a la opinión pública fue la demonización del enemigo ${ }^{30}$. Muchas fueron las plumas que aceleraron la disputa entre borbones y austracistas apoyadas en el combate religioso ${ }^{31}$. En realidad, ambos bandos consideraban al enemigo como la guarida de satanás, pero quizá más intensamente el partido borbónico que, apoyado en la experiencia de la historia, alertó sobre el contagio de la herejía:

No padecen Alemania, Hungría y Holanda la tormenta de la Herejía, y el naufragio fuera de la Nave de San Pedro, porque los Soberanos hayan querido violentar a sus súbditos para que la abrazaran; sino muy al contrario, que oponiéndole los Emperadores y Reyes, fue más poderoso el contagio nacido de la comunicación para arrastrar a los infelices pueblos a su perdición, abrazando los errores de aquellos con quienes comunicaban ${ }^{32}$.

Algunas órdenes religiosas, como la de los Jerónimos, mantuvieron estrechos vínculos con los borbones. A través de dos monjes, P. Francisco Salgado y Juan Núñez, que escribieron sendas Historias Generales de la Orden de San Jerónimo, se constata el afecto de Felipe $\mathrm{V}$ por la comunidad jerónima ${ }^{33}$. Ambos autores, ostentosamente borbónicos, vieron en la irreligiosidad el principio que alimentaba la barbarie y crueldad de los austracistas:

La nación sufría los horrores de una guerra civil; sus pueblos eran saqueados y quemados; sus campos talados y desolados, y millares de hombres sacrificados al furor del soldado extranjero, o a la rabia y venganza de sus conciudadanos. Infinitos bárbaros, protestantes y ateístas atravesaron las provincias de España varias veces, dejando por todas partes las señales y vestigios más lastimosos de su ferocidad e irreligión ${ }^{34}$.

la guerra de Sucesión Española (1710-1713). Tesis doctoral. Universidad de Castilla-La Mancha, 2014. Vid. también LOSA SERRANO, Pedro. "La rivalidad propagandística entre Whigs y Tories sobre la batalla naval de Málaga en 1704». En La guerra de Sucesión Española y la opinión pública hispano-británica. Madrid: Sílex, 2014, pp. 55-68.

30. GonZÁlez CruZ, David. "La "demonización” del enemigo en el discurso bélico de la guerra de Sucesión Española». En Contreras Contreras, Jaime; Alvar EzQuerra, Alfredo y Ruiz Rodríguez, José Ignacio (coords.). Política y cultura en la época moderna: (cambios dinásticos, milenarismos, mesianismos y utopías). Alcalá de Henares: Servicio de Publicaciones de la Universidad de Alcalá de Henares, 2004, pp. 217-234.

31. GonzÁlez Cruz, David. "Los discursos religiosos propagandísticos en la estrategia de la Guerra de Sucesión». Libros de la Corte.es, 2013, 7, pp. 156-158. MARTínEZ GiL, Fernando. "Los sermones como cauce de propaganda política: la guerra de Sucesión». Obradoiro de Historia Moderna, 2011, 20, pp. 303-336.

32. Melo y Girón, Juan. Zelo cathólico..., op. cit.

33. CAMPOS y FERNÁNDEZ DE SEvilla, Javier. "La guerra de Sucesión Española vista a través de la historia general de la orden de San Jerónimo”. Cuadernos de Investigación Histórica, 2007, 24, pp. 57-98.

34. SAlgado, Francisco, OSH (Monasterio de San Jerónimo de Madrid). Quinta Parte de la Historia de la Orden de San Gerónimo. Biblioteca Real del Escorial, Ms. J.1.3. Historia de los años 1674-1800. Inédita, ff. 270-271. Vid. CAMPOS y FERnÁNDEZ DE SEVILla, Javier. Idem. 
Si la impiedad de los enemigos era detestable, existía un aspecto aún más abominable: la propagación de las ideas políticas a través de confesores traidores. Un decreto papal trató de poner freno a dicha práctica manifestando que si

hay algunos que maliciosamente persuaden, y solicitan a los Penitentes en la Confesión Sacramental la gravísima culpa de inobediencia, infidelidad, y rebelión, haciéndoles creer, que no les obliga el juramento de fidelidad, sin duda por parecerles más segura, y eficaz esta insinuación, y sugestiva en aquel Sagrado lugar, y tiempo, de que se valen, para eludir, y frustrar las penas a que los sujeta la referida disposición de su Santidad con manifiesto abuso del Santo Sacramento de la Penitencia y evidente ruina en lo espiritual, y temporal de estos Catolicísimos, y fidelísimos Reynos... ${ }^{35}$.

Acabada la guerra y tras la retirada de las tropas austriacas, el 3 de noviembre de 1710, Felipe V procedió a realizar su entrada triunfal en Madrid acompañado de los nobles leales a su causa. El recibimiento de los madrileños fue apoteósico, manifestado en grandes regocijos y aclamaciones y en numerosos versos populares y letrillas que ensalzaban con alegría y vivas el regreso de Felipe V y su familia a la corte.

\begin{tabular}{|l|l|}
\hline Ahora que Phelipe & Levantemos el grito \\
Vuelve a la Corte, & Diciendo viva \\
Saquemos de la Prensa & Viva Phelipe V \\
Los Corazones. & Con alegría $^{36}$. \\
\hline
\end{tabular}

\section{LAS CAMPAÑAS PROPAGANDÍSTICAS EN LAS CONTIENDAS MEDITERRÁNEAS}

El Tratado de Utrecht de 1713 impuso, sin embargo, duras condiciones a la Monarquía Hispánica que perdió todos sus territorios en los Países Bajos españoles y en Italia. Lo más doloroso fue el final de la presencia española en Nápoles, Cerdeña y Milán, pertenecientes a la Monarquía española desde los siglos XIV y XV, y que pasaron al Imperio Austriaco; Sicilia, isla vinculada a la Corona de Aragón

35. Melo y Girón, Juan. Zelo cathólico..., op. cit.

36. Letrilla curiosa, graciosa y entretenida, a la bienvenida a su Corte de nuestros Católicos y legitimos Reyes segunda vez triunfantes. (s. 1., s.i., s. a.). 2 h. BNE, VE 529/66. [http://bibliotecavirtualmadrid.org/bvmadrid_publicacion/i18n/catalogo_imagenes/grupo.cmd?path=1001057]. Vid. también "Debidas aclamaciones al incomparable valor de nuestro amado Monarca Don Phelipe Quinto... en la restauración de sus perdidos vasallos (versificado, en pie de romance)». s. 1., s. i., s. a. [4] pp. En Curioso plantel matizado de muchos floridos conceptos, que ilustran varios papeles discretos, y curiosos en verso, escritos por algunos de los ingenios grandes desta Corte en digno aplauso de nuestro Monarca y Señor Don Phelipe Quinto e Magnanimo, que Dios guarde. En Madrid: [s. n.], 1711. P. R., Real Biblioteca VIII/53. 
desde 1282, fue trasferida al duque de Saboya. Aquella sensible pérdida de influencia en el Mediterráneo propició la provocadora política exterior de Felipe V durante el resto de su reinado con el fin de recuperar Italia y su influencia en el Mediterráneo. A partir de 1715, el monarca dirigió no solo sus deseos a aquellos territorios, sino también sus barcos y ejércitos provocando la guerra de la Cuádruple Alianza (1717-1721) y participando en la guerra de Sucesión de Polonia (1733-1735) y en la de Sucesión de Austria (1741-1748). La política revisionista italiana fue dirigida por Alberoni, agente del duque de Parma y ministro de Felipe $\mathrm{V}$, quien se convirtió en el instrumento para la revisión de los tratados de Utrecht y la recuperación de los territorios italianos ${ }^{37}$. Fue precisamente la reina Isabel de Farnesio la que mantuvo con tenacidad aquella política exterior con la que pretendía encontrar tronos para sus hijos, los infantes Carlos y Felipe.

Las primeras conquistas resultaron un éxito desde el punto de vista militar. La expedición de Cerdeña fue dirigida entre agosto y noviembre de 1717 por el marqués de Lede, un flamenco al servicio de España ${ }^{38}$. Las tropas apoyadas por la Armada española derrotaron fácilmente al ejército austro-imperial el 22 de agosto de 1717 y conquistaron la isla (1717-1721). Para dar legitimidad a aquel golpe, el Gobierno de España trató, por un lado, de inclinar a la opinión pública italiana hacia el afecto por los vínculos centenarios con la Corona española y, por otro, procedió a justificar los motivos de su actuación basados fundamentalmente en la agresiva conducta del emperador. Cuando desembarcaron en Cerdeña, las tropas españolas se encontraron con la grata sorpresa de la buena acogida de los naturales ${ }^{39}$. Aquello se debió en gran parte a las orientaciones de solicitud y magnanimidad que el gobierno de Felipe V había dado a sus ministros en Italia para conquistar las voluntades:

Tratareis de hablar con algunos de sus naturales, agasajarlos, y compadecerlos de lo que padecen, y darles a entender les mantengo la memoria y el amor de Padre y de buen Rey, y conservareys y cultivareys en su Corazón las raices de fidelidad y ternura que es de creer se conserven en ellos, tanto por la memoria de buen trato que lograron en mi Dominio, como por la experiencia del diferente que ahora padecen ${ }^{40}$.

Para justificar y respaldar los motivos de la conquista de Cerdeña, el secretario de Estado, marqués de Grimaldo, acometió una campaña propagandística cuya

37. Sallés Villaseca, Nuria. Giulio Alberoni y la dirección de la política exterior española después de los tratados de Utrecht (1715-1719). Barcelona: Universitat Pompeu Fabra, 2016.

38. Vid. Alonso Aguilera, Miguel Ángel. La conquista y el dominio español de Cerdeña (1717-1720): introducción a la política española en el Mediterráneo posterior a la Paz de Utrecht. Valladolid: Universidad de Valladolid, 1977.

39. Maqueda Abreu, Consuelo. "En torno al Decreto de Nueva Planta de Cerdeña, 1717-1720". Revista de Derecho UNED, 2006, 1, pp. 425-468.

40. Artículo 13 de las Instrucciones del rey al marqués de San Felipe a su llegada a Génova, septiembre de 1715. AGS, ES, Leg. 5435. Cit. por MaQueda Abreu, Consuelo. Idem. 
estrategia consistió en la publicación y circulación del manifiesto Mundo Político $y$ Cristiano. El escrito fue enviado el 9 de agosto de 1717 a los representantes diplomáticos españoles establecidos en diferentes capitales europeas con el fin de influir en la opinión pública. Las razones esgrimidas para explicar el ataque se basaron primordialmente en la necesidad de respuesta ante las actuaciones agresivas de Carlos VI contra España. El emperador había roto la paz y la neutralidad italiana en innumerables ocasiones; había contribuido a que los disidentes de Barcelona y Mallorca resistieran varios meses en su obstinación, al incumplir el acuerdo de evacuar Cataluña en 1713, sin olvidar la llegada de constantes refuerzos al Principado desde la isla; pero, sobre todo, el emperador había agradecido la ayuda naval española en Corfú con el ignominioso apresamiento del inquisidor general Molines.

La respuesta a la campaña propagandística de Grimaldo no se hizo esperar. En Holanda, el embajador español marqués de Bereti Landi recibió una réplica negativa de su Gobierno a la memoria de Grimaldo a través de la declaración "Consideraciones contra la Memoria presentada por el embajador Bereti Landi a los Estados Generales el 21 de septiembre de1717 sobre la carta circular del marqués de Grimaldo comunicada por este ministro a las autoridades». En ella argumentaba que el duque de Anjou mantenía sin sustento legal la parte más importante de la monarquía de España y que su Memoria buscaba el enfrentamiento y ocultaba la verdad ${ }^{41}$.

También la corte de Viena reaccionó ante las acusaciones de España orquestando su propia campaña para contrarrestar las quejas y reproches españoles. Según Amor de Soria, disidente español en Austria, Carlos VI respondió con toda moderación y eficaz comedimiento el 27 de septiembre de 1717 denunciando la ocupación de Cerdeña y presentándose como damnificado, pues fue atacado por España cuando defendía a la cristiandad contra los turcos. Al mismo tiempo, la corte de Viena publicó un impreso titulado «Respuesta de Pedro Claros español, retirado en Roma desde el año 1700, a un amigo sobre el manifiesto del secretario Grimaldo de 9 de agosto de 1717», un escrito irónico y lleno de chistes donde se descubrían los manejos y las negociaciones secretas españolas que precedieron a la invasión ${ }^{42}$.

En julio del año siguiente, otra expedición española conquistó rápidamente Sicilia, siendo recibida también con satisfacción por los sicilianos. Aquella feliz

41. GonZÁlez MezQuita, María Luz. «Alberoni y la revisión del sistema de Utrecht: buscar la neutralidad y conquistar la opinión". En Sociedad, cultura y política en el Antiguo Régimen: Prácticas y representaciones en la Monarquía de España. Mar del Plata: Ed. Biblos, 2019, pp. 251-276. Alabrús IgLESIAS, Rosa María. "La trayectoria de la opinión política en la España moderna». Obradoiro de Historia Moderna, 2011, 20, pp. 337-354, p. 350.

42. Claros, Pedro. Respuesta de Pedro Claros, español retirado en Roma desde el año 1700 , à un amigo, sobre el manifiesto del Secretario Grimaldo de 9 de agosto de 1717. Parma?: s. n., ca. 1717. Real Biblioteca de Madrid, MC/1013 (2). 
victoria de la Monarquía desencadenó, sin embargo, la guerra de la Cuádruple Alianza, con la firma del Tratado de Londres el 2 de agosto de 1718. Pronto a la alegría de la conquista le siguió la amargura del fracaso, como lo corroboró Amor de Soria:

Y como penetró (el rey Felipe) que la Sicilia se agregaba al emperador y la Cerdeña al duque de Saboya, pensaron ocupar ambos reinos para estorbar el efecto del tratado, imaginándose que ni los ingleses ni los franceses osarían emprender la guerra contra España, en que se engañaron como se vio al año siguiente ${ }^{43}$.

Efectivamente, la derrota naval de cabo Passaro, el 11 de agosto de 1718, fue un duro golpe para España. La Armada inglesa capitaneada por George W. Byng se dirigió sin mediar palabra contra la Armada española comandada por Antonio Gaztañeta y Fernando Chacón ${ }^{44}$. La falta de una declaración formal de guerra y la táctica naval inglesa de navegar de forma dispersa no alarmaron a las tropas españolas que se vieron sorprendidas como señalaron en la "Relación de la batalla", en la que declararon "la falta de apariencia" como causa de su inadvertencia ${ }^{45}$.

Como era de esperar, un gran número de pinturas y grabados de autoría inglesa reprodujo la derrota española. En el lienzo de Gaspar Butler, La Armada del Almirante Byng en Nápoles, se observan las características propagandísticas de la época. Dilatados escenarios para resaltar las extensas y bien dispuestas fuerzas navales británicas, con las instalaciones portuarias de la ciudad de Nápoles al fondo donde la flota británica parece dominar a sus anchas. El pintor revela los detalles de unos 23 navíos de gran calado con sus banderas, entre los que destaca en primerísimo plano el buque insignia del almirante Byng, el Barfleur, con un extraordinario poder de fuego de 90 cañones. Todos estos elementos iconográficos ofrecen la imagen de cohesión y poder de la flota británica, la cual, según las "Memorias" del marqués de la Mina, constaba de 21 navíos, dos brulotes, dos bombardas, dos transportes y un hospital, con un total de 1.360 cañones y 8.490 hombres $^{46}$.

43. LEÓN SANZ, Virginia. "El conde Amor de Soria: Una imagen austracista de Europa después de la paz de Utrecht». En Guimerá, A. y Peralta Ruiz, V. (coords.). El equilibrio de los Imperios: de Utrecht a Trafalgar. Madrid: Fundación Española de Historia Moderna, 2005, pp. 133-154, p. 140.

44. Vid. STORRS, Christopher. The Spanish Resurgence, 1713-1748. New Haven, Connecticut: Yale University Press, 2016.

45. Relación verídica del combate que el día 11 de Agosto de 1718, bubo entre la Armada de España y la de Inglaterra en las Costas Orientales de Sicilia y en el Canal de Malta. En Madrid: en la Imprenta de Juan de Aritzia, 1718.

46. GuZmán DÁvalos, Jaime Miguel de, Marqués de la Mina. Memorias sobre la Guerra de Cerdeña y Sicilia en los años de 1717 a 1720 y Guerra de Lombardía en los de 1734 a 1736 . Madrid, ed. de 1898. 


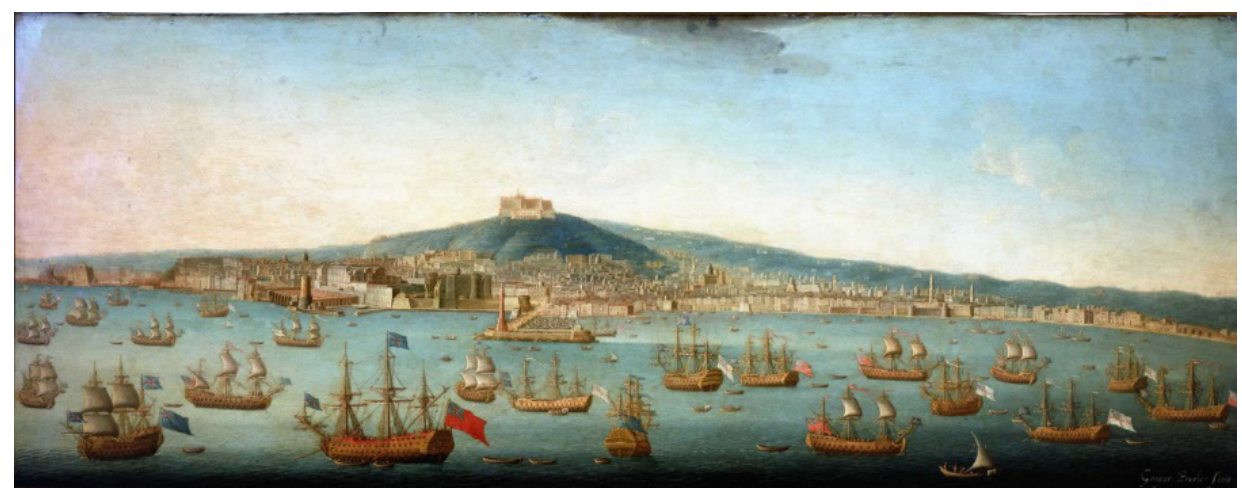

Fig. 1. Admiral Byng's Fleet at Naples, 1 August 1718, by Gaspar Butler or Kaspar Botler.

La fuerza naval de Byng comenzó la persecución de la flota española partiendo de Nápoles, cruzando el estrecho de Mesina y dirigiéndose por la costa este de Sicilia hacia el cabo Passaro. El contingente español, formado por 29 navíos de guerra, 2 brulotes, 6 galeras y otros barcos con provisiones ${ }^{47}$, antes de llegar al cabo se dividió en dos, una parte se dirigió a la costa y la otra se vio comprometida con los principales perseguidores ingleses. En el siguiente mapa pueden apreciarse la división de la flota española y el paso de los barcos británicos por el estrecho de Mesina. También puede distinguirse, entre las ruinas de la antigua colonia griega de Megara, a dos barcos españoles ardiendo y a un tercero bajo fuego enemigo.

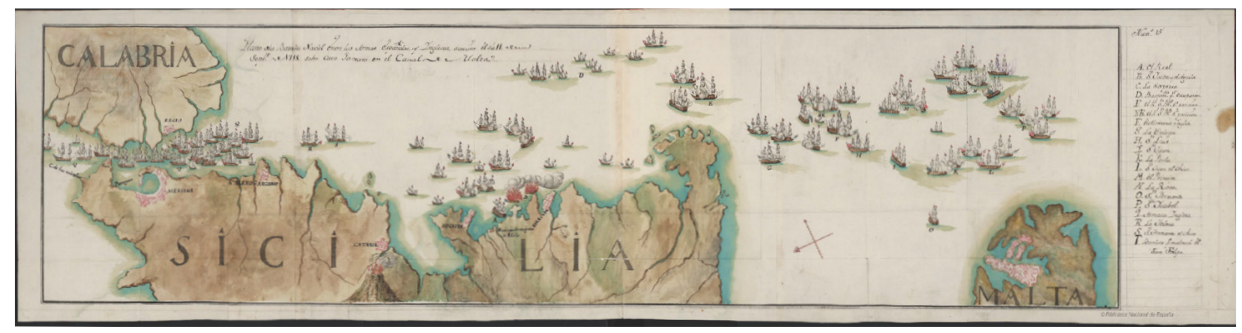

Fig. 2. Plano de la batalla naval entre las Armas españolas y Ynglesas acaecida el dia 11 de septiembre de 1718 sobre Cabo Passaro en el canal de Malta ${ }^{48}$.

47. Ibid.

48. Detalle del mapa de la batalla naval en Cabo Passaro 1718, en tinta y acuarela. Colección de cuadros y planos sobre la guerra de Cerdeña y Sicilia, en los años 1717 a 1720 . Mapa 15 de la Colección. Madrid: BNE, Mss 6408. 
No menos propagandística que la pintura de Gaspar Butler fue la de Isaac Sailmaker que recoge uno de los momentos de la batalla naval. En el centro, el buque insignia español -el San Felipe el Real comandado por el general Antonio Gaztañeta con 74 cañones a bordo- está flanqueado por dos barcos ingleses a cada lado -probablemente el Superbe y el Kent- y acosado por un duro bombardeo $^{49}$. Asimismo, en primer plano se pueden observar dos navíos españoles prácticamente hundidos, de los que solo se ve la bandera, y un tercero a la derecha gravemente incendiado. El mensaje de la victoria inglesa es aplastante.

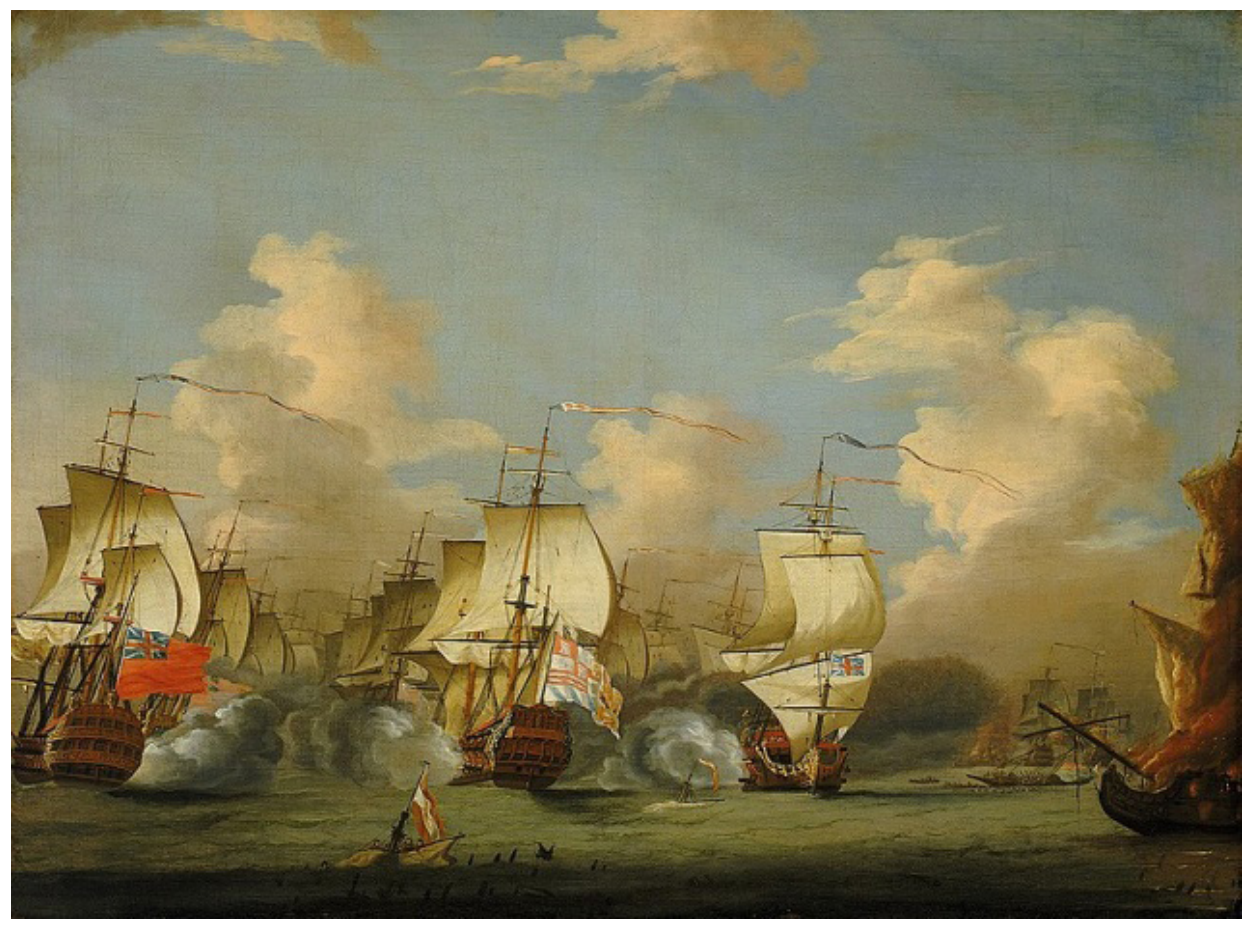

Fig. 3. The Spanish flagship San Felipe flanked on either side by British ships, probably Superbe and Kent - painting by Isaac Sailmaker.

En la pintura de Richard Paton, realizada en 1767, 50 años después del acontecimiento, el autor utiliza también una iconografía propagandística. En el centro, el buque insignia británico, el Barfleur, se representa de modo prominente disparando desde su costado de estribor contra el navío español San Luis, de 60

49. Según las Memorias de Mina, el San Felipe, apresado por los ingleses, se incendió posteriormente por descuido y voló con 160 ingleses y 50 españoles a bordo. 
cañones. A la derecha, el principal buque insignia español, el Real San Felipe, se muestra a estribor con el Superbe, de 60 cañones, y arrastrando su bandera hacia abajo. A la izquierda de este grupo, un barco español yace en su costado de estribor. A la derecha y a lo lejos, otro navío español está navegando muy comprometido en ambos lados. El mensaje del poderío naval inglés derrotando al principal enemigo de Inglaterra es patente. La pintura fue exhibida en la Sociedad de Artistas de Londres en 1767 y 1768.

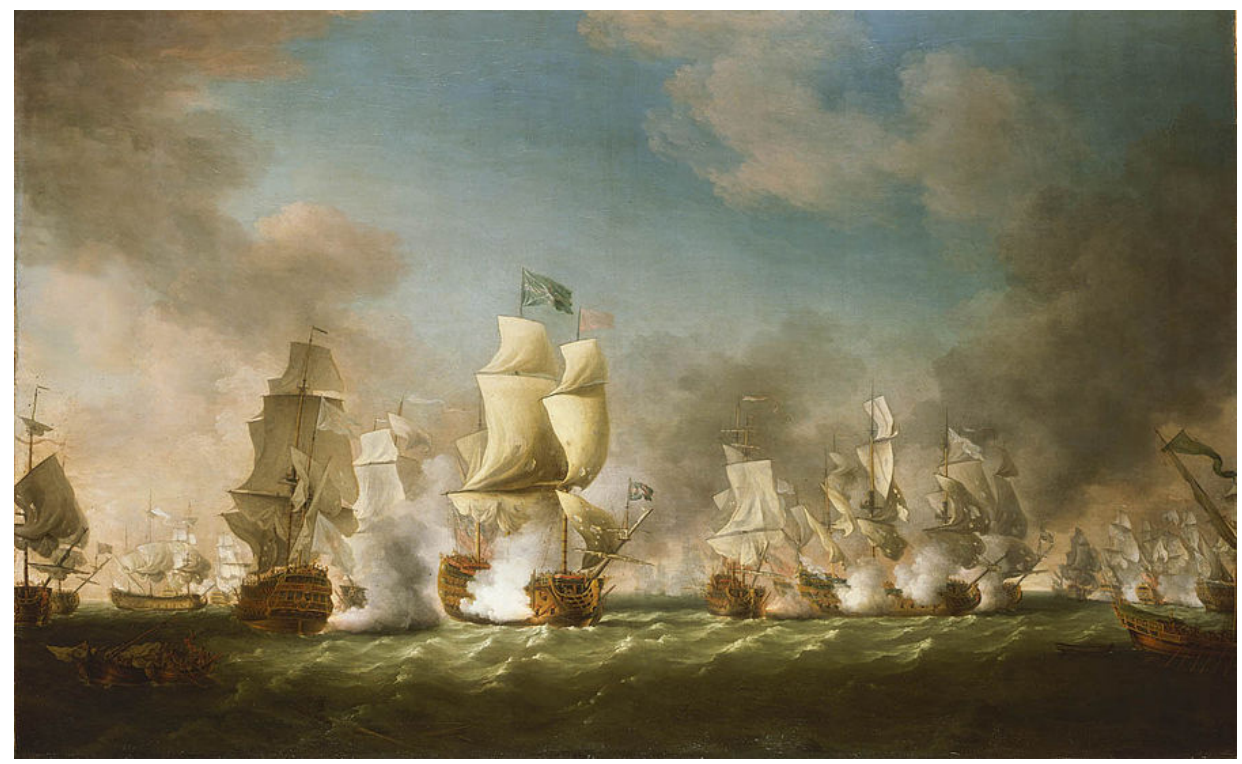

Fig. 4. The battle of Cape Passaro by Richard Paton.

Otras láminas ofrecen distintas perspectivas de la victoria inglesa. En la de Peter Monamy se observa claramente la táctica británica. Aunque la batalla duró desde el amanecer hasta el anochecer, el pintor representa de manera simultánea ocho enfrentamientos de navíos individuales, todos ellos victoriosos para los ingleses. La pintura muestra con detalle la táctica arrolladora de la armada inglesa en alta mar que consistió en encajonar a los barcos españoles. Por ejemplo, en el recuadro 2 se representa al Real San Felipe que perseguido por el Kent, y probablemente el Superbe, fue finalmente capturado. En el recuadro 6, el navío español Volante es acosado y encajonado entre el Montague y el Rupert, y en el recuadro 7, el Príncipe de Asturias se encuentra del mismo modo hostigado por el Breda 
y el Captain $^{50}$. De la flota española, 16 navíos fueron apresados y 7 quemados. La captura del buque insignia San Felipe fue un tema recurrente en la pintura y grabado de temática naval. Se forjó así un modelo propagandístico del poderío inglés, muy utilizado por otros pintores como, por ejemplo, Humphrey Vale.

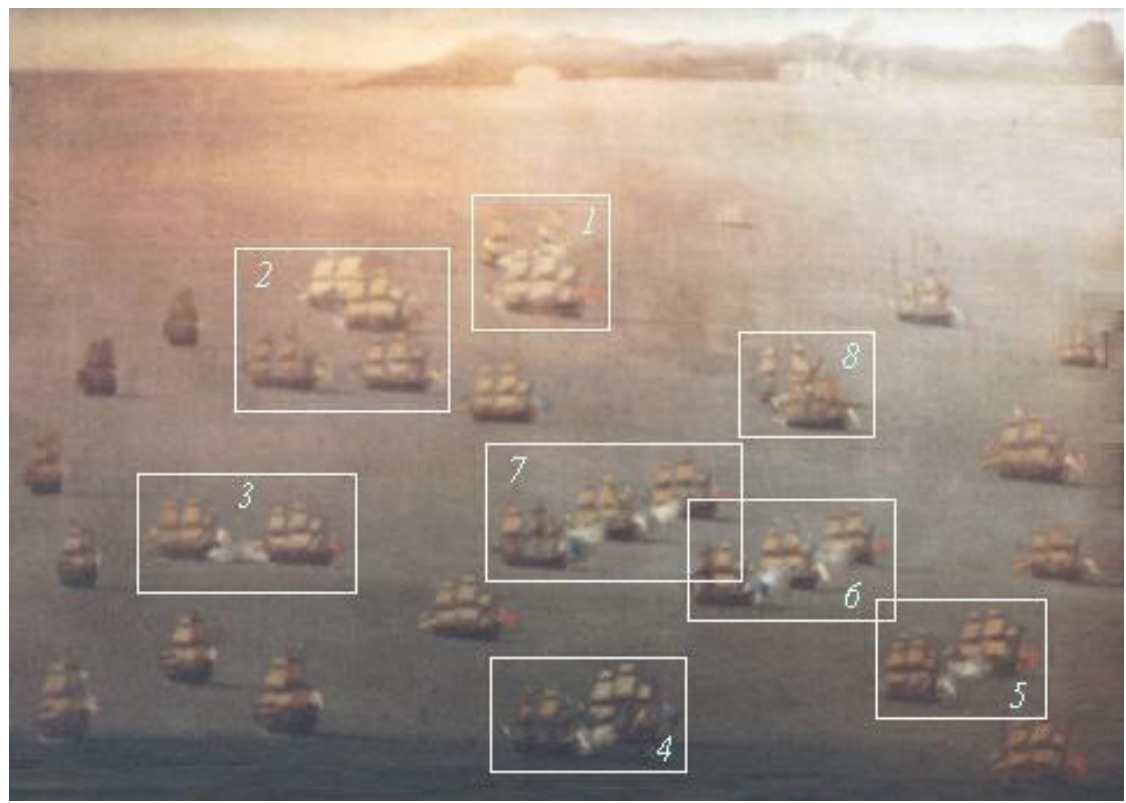

Fig. 5. The Battle of Cape Passaro by Peter Monamy, ca. 1725. Pintura al óleo.

50. Vid. el análisis de la pintura en https://www.cichw1.net/pmbapass1.html y https://www. cichw1.net/pmbapass2.html. 


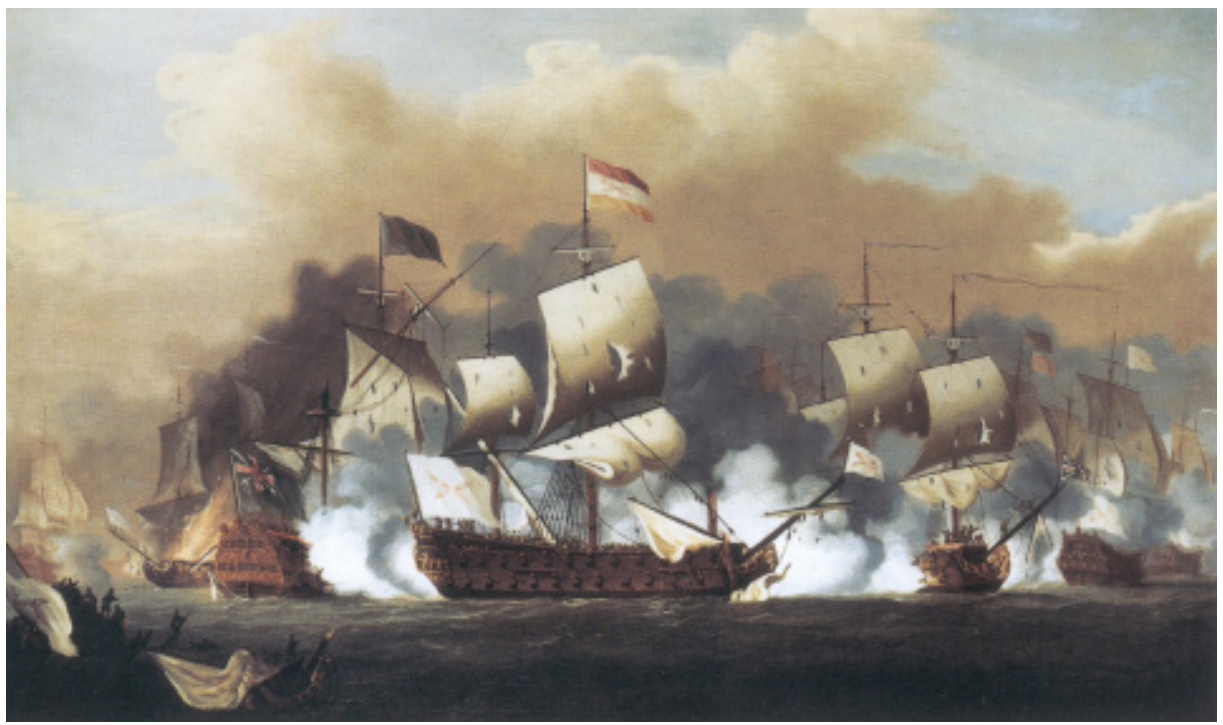

Fig. 6. Capture of the Real San Felipe at Cape Passaro, by Humphrey Vale.

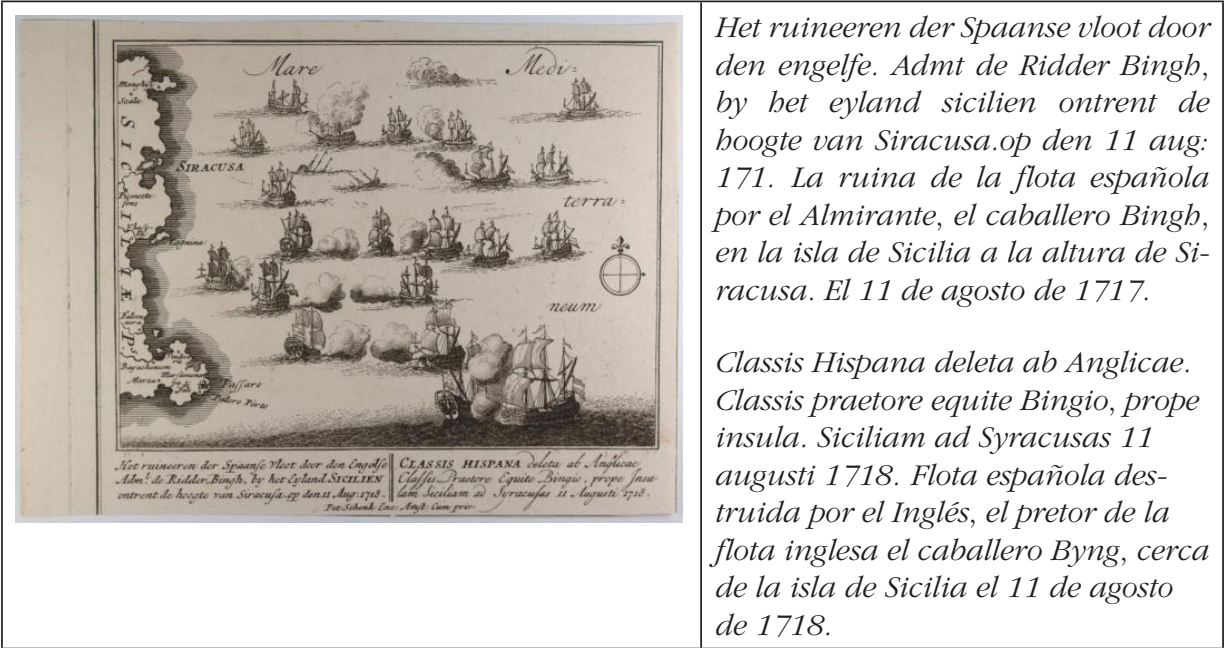

Fig. 7. Dibujo original de Adolf van der Laan (1685?-1755), grabado por Leon Schenk, impreso por Peter Schenk el Joven, Ámsterdam, ca. 1730. 
En la misma línea propagandística, se encuentra el dibujo del mapa de la batalla del cabo Passaro realizado por el flamenco Adolf van der Laan. En él se han incluido dos epígrafes, elemento habitual en estos siglos para consignar el acontecimiento sin margen para el olvido o el error. Las dos lenguas utilizadas, el neerlandés (propia del autor) y el latín, buscaban la mayor difusión posible en Holanda y en un público culto. En las dos inscripciones se consigna la ruina o destrucción de la flota española; el nombre del vencedor, el almirante Byng de la flota inglesa, el lugar y la fecha. En él se observan los cañoneos, la táctica naval de hostigamiento y la captura de los navíos españoles, los incendios y el hundimiento de algunos de ellos.

No podía faltar, para explotar aún más el acontecimiento victorioso, la acuñación de medallas conmemorativas. La medalla de la victoria del cabo Passaro presenta visibles elementos de carácter propagandístico. En el anverso dentro de dos coronas de laurel los bustos victoriosos del emperador Carlos VI [CAROLVS VI. D. G. ROM. IMP. SEMP. AVG] y el rey de Inglaterra Jorge I [GEORGIVS. D. G. MAG. BR. FR. ET. HIB R], uno frente al otro y entre ellos un caduceo o vara que se eleva desde una galera antigua. La inscripción de la medalla dice así: VEDANT FOEDARI FOEDERA. ("Prohibido violar los Tratados", aludiendo a la inobservancia de los tratados de Utrecht por parte del rey de España Felipe V).

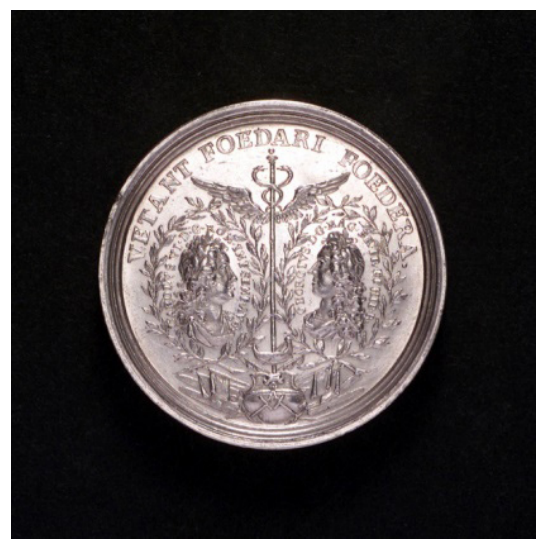

Fig. 8. Anverso de la medalla conmemorativa de la victoria del cabo Passaro, 1718.

En el reverso de la medalla se representa a Júpiter llevado por un águila -simbolizando al emperador- y a Neptuno -representando al rey de Inglaterraatacando ambos una flota (izquierda). La leyenda, continuación de la del anverso, expresa que: SIC MOTOS FAS EST COMPONERE FLVCTVS. («Por lo tanto, es correcto calmar las olas turbulentas»). Debajo, para evitar errores y olvidos, el exergo afirma el carácter propagandístico al señalar: CLASIS DE HISPANORVM A IOVE ET 
NEPTVNO DELETA. ("La flota española destruida por Júpiter y Neptuno», es decir, por Austria e Inglaterra $)^{51}$.

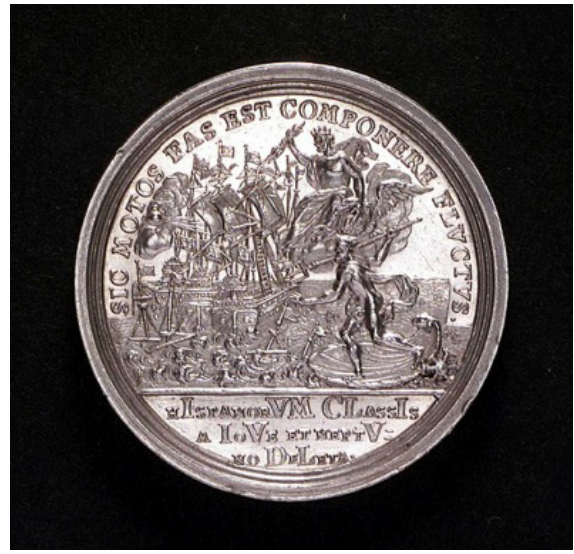

Fig. 9. Reverso de la medalla conmemorativa de la victoria del cabo Passaro, 1718.

Una práctica habitual para acrecentar el alcance e impacto de la victoria consistía en la exageración de las dificultades encontradas en la batalla. En los informes ingleses se describieron graves aprietos debidos a la poderosa fuerza del enemigo español, declaración que causó diversas polémicas en la prensa inglesa. The Flying Post se burló del relato de la victoria naval británica frente al cabo Passaro que publicó el Daily Courant, afirmando que esa representación del poder, la valentía española y el engaño inglés eran comparables al Pantagruel de Rabelais. También se cuestionó al Post-Boy y al Weekly Journal por exagerar la fuerza naval española ${ }^{52}$.

Tras la destrucción en el cabo Passaro, a pesar de la falta de apoyo naval, las tropas españolas que permanecían en Sicilia, dirigidas una vez más por el marqués de Lede y el conde de Montemar, libraron el 20 de junio de 1719 en Francavilla una de las batallas más mortíferas de la guerra, tanto que algunos la han considerado la mayor batalla en Sicilia desde la antigüedad ${ }^{53}$. La victoria española confirmó lo que se intuía desde Almansa, que las reformas militares de Felipe V habían convertido al ejército español en una fuerza a tener en cuenta. En Francavilla, el ejército apoyado por las milicias locales consiguió derrotar a las tropas

51. Escuela de Núremberg, 1718, por Vestner, G.W. Alemania.

52. Black, Jeremy. The English Press in the Eighteenth Century. Nueva York: Routledge Revivals, 1. ${ }^{a}$ ed. 1987 , ed. 2011, p. 145 .

53. Boeri, Giancarlo; Giacomone Piana, Paolo y Mirecki Quintero, José Luis de. "La batalla de Francavilla". Desperta Ferro: Historia Moderna, 2019, 39, pp. 44-49. 
imperiales del conde de Mercy. También durante el avance, las fuerzas austriacas sufrieron numerosos enfrentamientos con la población local que se opuso a ellos obstaculizándoles el paso. La política de atracción de los naturales hacia la Corona española había dado su resultado. Mina no consignó el número de tales milicianos, pero el embajador saboyano en Nápoles ofreció la cifra de 12.000 paisanos a lo largo de la guerra.

La noticia de la victoria española de Francavilla tuvo un eco extraordinario en la prensa de la época, aquella ciudad siciliana se convirtió durante un tiempo en el ombligo del mundo. En España, la victoria fue difundida y ensalzada no solo por parte de la Gaceta oficial de Madrid ${ }^{54}$, sino también por numerosos impresos como la Relación de la batalla de Francavilla en Sicilia, un triunfo bélico para las armas españolas $^{55}$. En Italia aparecieron diversas publicaciones sobre la batalla, como El Diario de todo lo que sucedió en la última guerra de Sicilia por los ejércitos de Austria y España... ${ }^{56}$, que relató el combate incluyendo un grabado muy detallista del campo de batalla, el asedio de Messina y los campamentos de las tropas en Arenella, cerca de Palermo. El dibujo fue utilizado más tarde por el pintor holandés Orazio Grevenbroeck (1678-1730) para realizar su pintura Battaglia di Francavilla. En el lienzo, aparece al fondo el campamento atrincherado mandado disponer por el general español, que supo elegir una posición estratégica óptima con la intención de atraer al ejército austriaco del conde de Mercy a un terreno favorable para la defensa, pero adverso para ellos. La victoria española fue rotunda. La pintura, sin ser propagandística, se considera una auténtica estampa ilustrativa, un testimonio documental único de aquel 20 de junio de 1719, debido a la importancia otorgada a la descripción topográfica en la que se destaca la entrada a las 'gargantas del río Alcántara' a la izquierda y el imponente volcán Etna al fondo en erupción. Asimismo, el monte San Giovanni, la colina del monasterio de los capuchinos en el centro y la colina del castillo, rodeado de grandes fosos y artillería que impedían el acceso desde cualquier frente. También es notable la descripción minuciosa urbana, con el diseño de la ciudad y sus elementos arquitectónicos y, sobre todo, el discurso visual bélico en el que pueden observarse detalladamente los despliegues de las fuerzas en el campo y su distribución en el

54. La Haya, 2 de agosto de 1719. El marqués Berreti-Landi hizo imprimir una "Relación en lengua francesa sacada de las cartas de diferentes ministros de España de la batalla que se dio el día 20 de Junio en el Campo de Francavilla de Sicilia, la qual destruye enteramente todo lo que los Alemanes habían publicado". Gaceta de Madrid, n. ${ }^{\circ}$ 34, de 22 agosto 1719, pp. 135 a 136 [BOE-A-1719-265].

55. Relación de la batalla que se dio en el campo de batalla de Francavilla en Sicilia, el 20 de Junio de 1719 entre el ejército de Su Majestad y el de los alemanes. Madrid: Juan de Aritzia, 1719, 8 pp. Vid. en BNE y en Archivo Documental Español Publicado por la Real Academia de la Historia. En 2019, la batalla fue rememorada en Francavilla en su tricentenario.

56. COLPI, Francesco de. Diario di tutto quello che successe nell ultima guerra di Sicilia fra le due armate Allemana e Spagnuola. Con un breve ristretto de fatti principali attinenti à questa guerra dal 1713 che fù stabilito il Trattato d Utrecht sino ad hora presente. Tutte notitie raccolte da molte veridiche Relationi. Diviso in due parti. Parte prima (e seconda). Colonia, ma Palermo, 1721. 
territorio, la exactitud del campamento, la batalla, el fuego de la artillería. Todo ello enriquecido por una extraordinaria calidad y realismo.

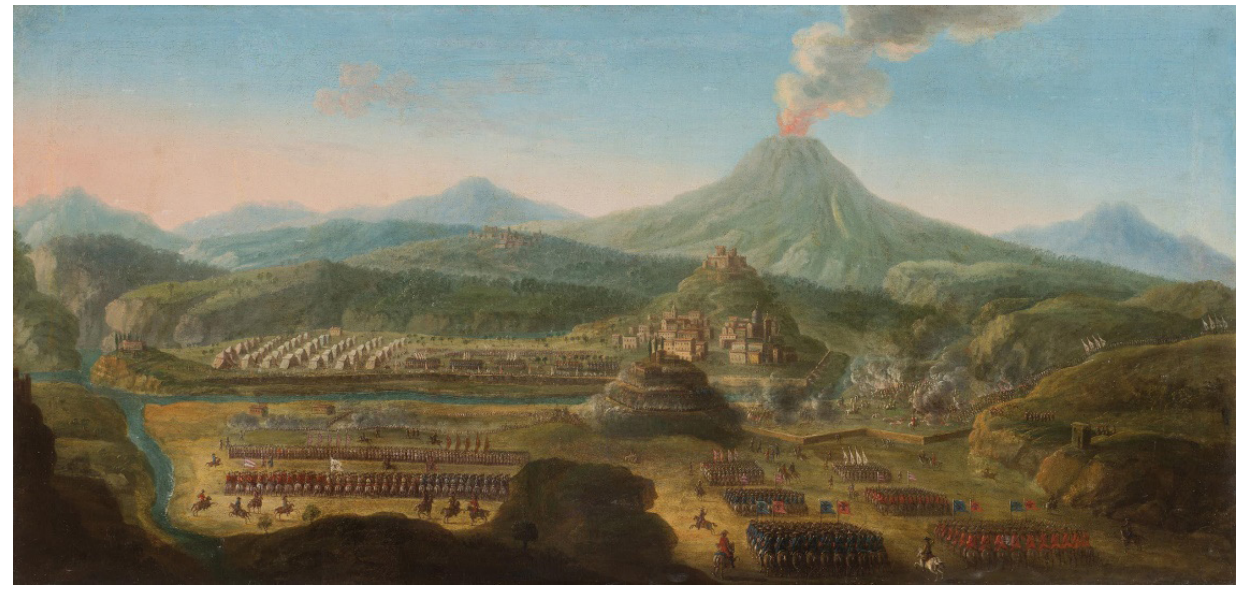

Fig. 10. Battaglia di Francavilla por Orazio Grevenbroeck.

La guerra de Sicilia terminó en febrero de 1720, cuando Felipe V se vio obligado a firmar en La Haya la retirada de las tropas de Cerdeña y de Sicilia donde solo consiguió una promesa: que la sucesión a los ducados de Parma, Piacenza y Toscana recaería en Carlos, hijo de los reyes de España.

Felipe V no abandonó, por ello, su política de recuperación de influencia en el Mediterráneo. Con 16.000 soldados que regresaban de la guerra de la Cuádruple Alianza formó la expedición que se dirigió en 1720 a liberar Ceuta del larguísimo asedio de 26 años de los marroquíes a cuyo frente estaba Muley Ismail. La victoria del marqués de Lede, quien logró que los sitiadores se retiraran a Tetuán, tuvo gran eco en España, aunque sus resultados fueran fugaces. Entre las diversas Relaciones de la batalla publicadas con motivo de la liberación de Ceuta destaca la

Nueva Relación en un curioso Romance en que da cuenta y declara la victoriosa refriega que consiguieron las armas de nuestro Católico Monarca don Felipe Quinto (que Dios guarde) el día 17 de octubre contra la secta Mahometana que tenía puesto sitio a la plaza de Ceuta y del destrozo que hicieron dando muerte a cinco mil moros, habiéndose huido el Baxá en camisa, y de los pertrechos de guerra que le cogieron y entre ellos la bandera general. Con los demás que verá el curioso lector ${ }^{57}$.

57. BUS (Biblioteca Universitaria de Sevilla), 109-36. El autor de la idea dice ser un "ingenio" cordobés. Cit. por Morales, Nicolás y Quiles García, Fernando (coords.). Sevilla y corte: las artes y el lustro real (1729-1733). Madrid: Casa de Velázquez, 2010, p. 259. 
Solo el título contiene elementos propagandísticos dignos de ser analizados. Los triunfadores no son los soldados, ni siquiera el ejército por sí mismo, sino «las armas de nuestro Católico Monarca», es decir, el ejército del rey. Los vencidos son los enemigos que en este caso se identifican con la secta Mabometana, dando a la empresa un discurso religioso y de cruzada. Los resultados de la victoria se contabilizan siempre por el número de muertos, heridos y desaparecidos y por los despojos recogidos, especialmente armas y banderas, de ahí las cifras señaladas y los trofeos cosechados: "... dando muerte a cinco mil moros, [...] y de los pertrechos de guerra que le cogieron y entre ellos la bandera general». La victoria alcanzó tal punto que una simple descripción es suficiente para mostrar su totalidad: "habiéndose huido el Baxá en camisa».

Asimismo, un famoso grabado -Victoria contra el sitio de Muley Ismail, 15 de noviembre de 1720 - inmortalizó la batalla y ensalzó al comandante de la expedición, el marqués de Lede. En primer plano, aparece el marqués a caballo dirigiendo el ataque contra los sitiadores de Ceuta. El modelo clásico del alazán en corveta viene a demostrar que la práctica de dominio del combate por parte del general no es menor que la que evidencia sobre el corcel. Siguiendo la iconografía tradicional de la representación de las batallas, el general victorioso destaca por encima de todo y de todos desde una situación de altura, pero en este caso no está dando órdenes o señalando con el bastón de mando el objetivo, sino en plena lucha con la espada desenvainada, lo que hacer resaltar su valor. A derecha e izquierda está flanqueado por dos oficiales de su plana mayor y a sus pies los enemigos marroquíes cayendo ante el ímpetu arrollador de los españoles; todo ello en medio del fuego que produce la artillería. Se trata de un grabado propagandístico del general triunfante marqués de Lede y del ejército del rey, cuya inscripción en latín reza: CEUTA DUCTUS MARCHIONIS LEDACI OBLIVIONE LIBERATA. "Ceuta fue liberada del olvido por el general Marqués de Lede», 15 de noviembre de 1720]. 


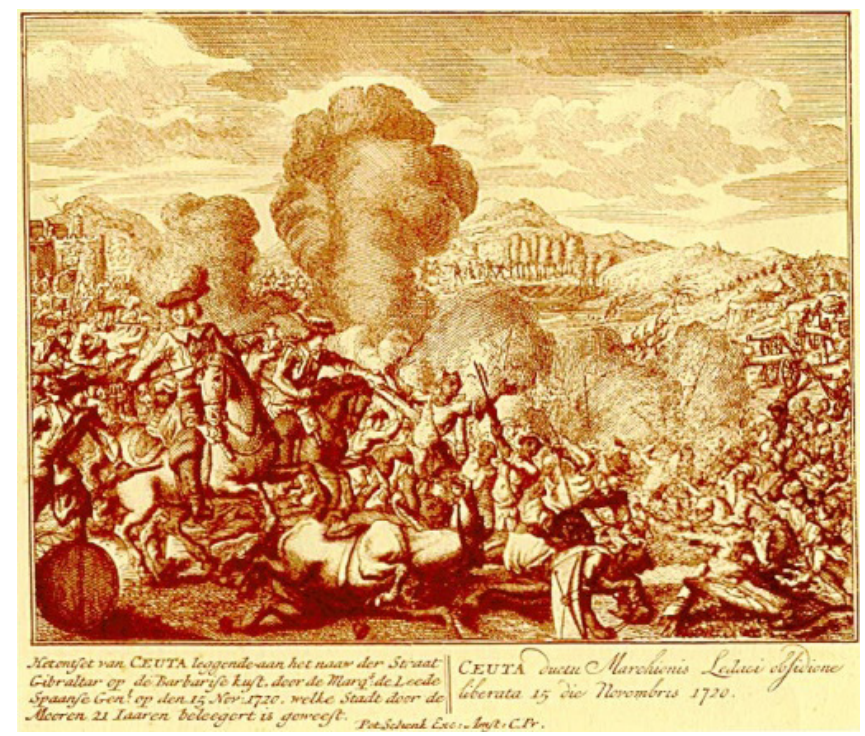

Fig. 11. Expedición del marqués de Lede a Ceuta. Victoria contra el sitio de Muley Ismail, 15 de noviembre de 1720.

Finalmente, si las expediciones victoriosas de 1717 a 1720 a Cerdeña, Sicilia y Ceuta, que tanta resonancia tuvieron en la opinión pública española y europea, no logaron sus objetivos, se debió a una inadecuada proyección política y diplomática. A partir de Utrecht era preciso contar con sólidos aliados y no aventurarse en provocaciones internacionales por mucho que las armas se demostrasen consistentes y profesionales. El triunfo solo era posible en coalición.

En las décadas de 1730 y 1740, la conquista de Orán y las contiendas de Italia -la guerra de Sucesión de Polonia y la de Sucesión de Austria- supusieron también un jalón en la historia de la propaganda del siglo XVIII. El deseo de recuperar los añorados territorios italianos perdidos en Utrecht y con ellos la influencia en el Mediterráneo seguía muy vivo en España. Cuando el 20 de enero de 1731 murió el duque Antonio de Parma se abrió la cuestión de la sucesión del infante Carlos de Borbón a los ducados, dando el impulso definitivo al pacto con el emperador. Finalmente, Austria reconoció el Tratado de Sevilla y ratificó la sucesión del infante a los ducados con la retirada de las tropas austriacas y la introducción de guarniciones españolas en Parma, Plasencia y la Toscana. Con el beneplácito de las principales potencias europeas, Felipe V orquestó una verdadera campaña de imagen y ostentación de poder ante Europa utilizando la magnífica expedición organizada por Patiño para la toma de posesión del infante a los ducados italianos. Con ello el rey enviaba un rotundo mensaje: no solo había recuperado su poder naval, después de la humillación que había supuesto la derrota del cabo Passaro, sino que estaba decidido a 
utilizarlo en el Mediterráneo. De ahí que proyectara un traslado por mar para poner a su hijo al frente del gobierno de Parma, Plasencia y Toscana y estacionar tropas que garantizaran su consolidación en el poder. Además, el rey quiso que el despliegue de ese recuperado poderío naval se hiciera de la forma más ostentosa posible ${ }^{58}$. El 20 de octubre de 1731, el infante Carlos con 15 años se despidió de sus padres en Sevilla, embarcó y llegó a Italia el 27 de diciembre convirtiéndose en duque de Parma. Allí, tutelado por Dorotea Neoburgo, la duquesa viuda, permaneció 4 años gobernando Parma, Piacenza y Toscana como duque.

Basado en su recuperado poderío naval, Felipe V acometió en 1732 la reconquista de Orán, plaza que España había perdido en 1708 durante la guerra de Sucesión española ${ }^{59}$. La toma de Orán no fue solamente una empresa en busca del prestigio dinástico de los Borbones españoles, fue también una acción militar encaminada a eliminar a Francia y a Gran Bretaña, dos potencias en auge en el Mediterráneo, del monopolio de un puerto de entrada y salida comercial en el norte de África ${ }^{60}$.

Como en toda empresa bélica, el rey tuvo que iniciar una campaña de propaganda a favor de su decisión explicando las causas de aquella "Jornada». Las alusiones a la restauración del orden perdido tras los tratados de Utrecht o la defensa de las costas hispanas de los ataques crecientes de los corsarios fueron explicaciones suficientes y válidas para persuadir a los súbditos y convencer a las cortes europeas ${ }^{61}$.

La toma de Orán, muy ensalzada por escritores y pintores, trajo consigo una explosión de noticias, diarios, versos, relaciones de sucesos y también láminas y lienzos conmemorativos en los que se ponía de relieve el creciente poderío español en el Mediterráneo ${ }^{62}$. Entre las obras manuscritas destacaron la del artillero Joaquín de la Ripa y la del soldado y poeta Eugenio Gerardo Lobo, conocido como el "capitán coplero». El primero escribió una autobiografía titulada Vida y aventuras del philo-matemático D. Joaquín de la Ripa y Blanque escrita por él mismo... en la guerra de Orán... ${ }^{63}$. En el texto destaca, además del peculiar interés humano, literario y sociológico, una complacencia sorprendente en lo truculento al relatar los avatares de la expedición. El segundo compuso el famoso Rasgo

58. BAudot, María. "El regreso de Felipe V a Italia después de la Guerra de Sucesión». RUHM, 2016, 5, 10, pp. 67-88.

59. SÁNCHez Doncel, Gregorio. Presencia de España en Orán, 1509-1792. Salamanca: Instituto Superior de Estudios Teológicos San Ildefonso, 1991.

60. FÉ CanTó, Luis F. «El desembarco en Orán en 1732». RUHM, 2016, 5, 10, pp. 89-110, p. 96.

61. Ibid.

62. López, Roberto J. «Un ejemplo de propaganda bélica: rogativas y festejos en Santiago por la toma de Orán en 1732". Semata: Ciencias sociais e humanidades, n. ${ }^{\circ}$ monográfico: Guerra, violencia e conflitividade na bistoria, 2008, 19, pp. 95-134.

63. Ripa, Joaquín de la. Vida y aventuras del philo-matemático D. Joaquín de la Ripa y Blanque escrita por él mismo en que da noticia de las campañas y funciones que se ha hallado en la guerra de Orán y de Italia, con una escuela militar para ser perfecto soldado, y algunas imposiciones matemáticas. Madrid: Joseph González, 1745. 
Épico de la conquista de Orán que a la diversión de los oficiales de los Regimientos de Guardias españolas y valonas dedica la ociosidad de un compañeros suyo ${ }^{64}$. La obra se difundió ampliamente, pues tuvo varias reimpresiones en Barcelona, Valencia, Sevilla y Madrid. En ella, su autor dedicó un poema muy celebrado de exaltación de la batalla y glorificación de su general el conde de Montemar, victorioso frente a un enemigo temible y duro:

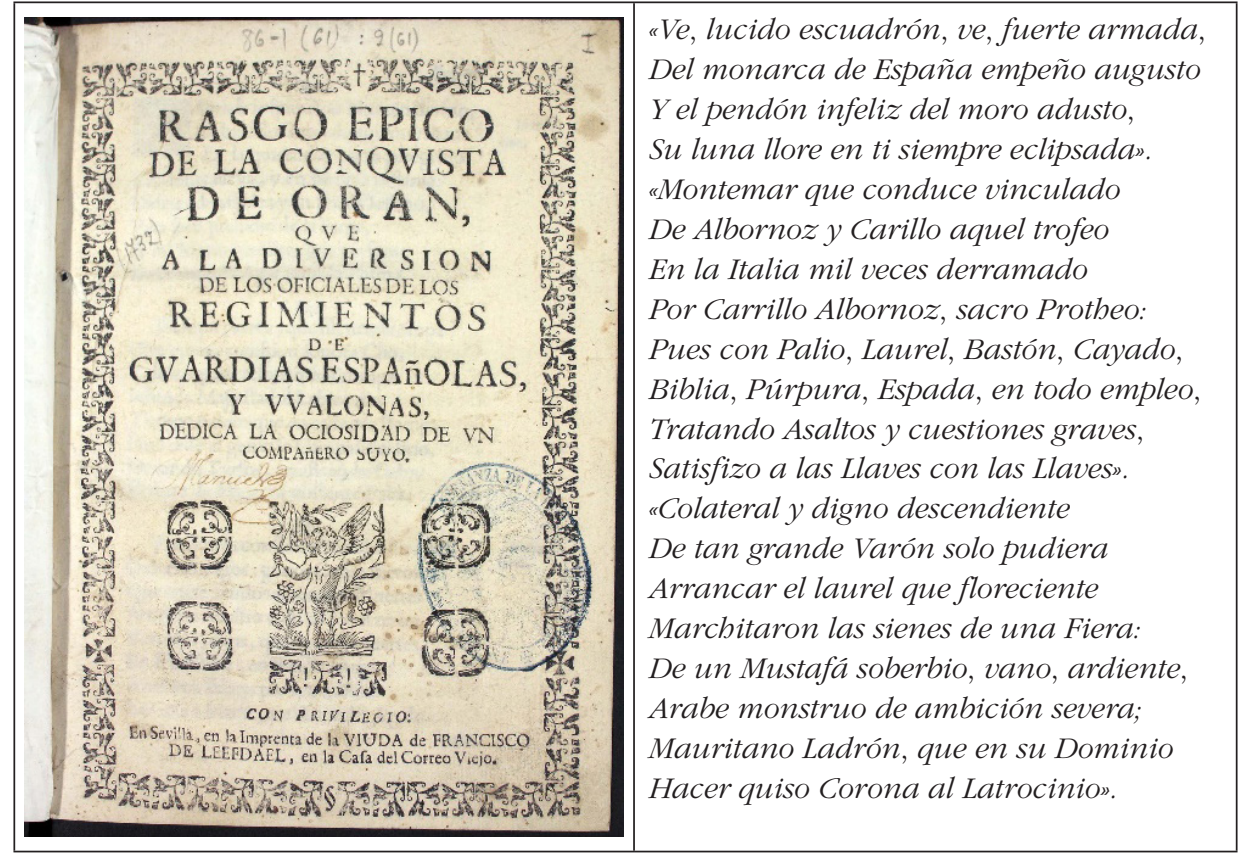

Fig. 12. Rasgo épico de la conquista de Orán.

Las noticias del triunfo dieron lugar también a la publicación de Relaciones de Sucesos en torno al acontecimiento:

RELACION de lo acaecido en la navegacion de la armada, que se congregó en la bahía de Alicante y de los... progressos del exercito del Rey en la conquista... de la Plaza de Oran en Africa en... este año de 1732.

64. LoBO, Eugenio Gerardo. Rasgo épico de la conquista de Orán que a la diversión de los oficiales de los regimientos de guardias españolas y valonas dedica la ociosidad de un compañero suyo [D.E.G.L.]. En Sevilla: en la Imprenta de la Viuda de Francisco de Leefdael, 1729-1733? 
La Relación finaliza con una apología de los triunfos alcanzados por las tropas del rey con un claro carácter propagandístico:

Estos triunfos, que después de la asistencia de Dios, se deben únicamente al invencible valor de las Tropas, ha restituido al Rey, y a la Corona esta tan importante Plaza [...] freno y dominio de los Africanos que infestaban las Playas y Costas de las provincias de España más vecinas, cuyos daños quedan reparados con este favorable suceso, como lo acredita la obediencia, que ya han ido dando los Lugares y parcialidades de aquellos contornos ${ }^{65}$.

El lenguaje laudatorio y elogioso impregna los títulos y narraciones de estas Relaciones de la batalla:

Iconismos, Encomiasticon, o Verdadera Descripción y elogio de la Expedición de Africa en que las Reales Armas de su Majestad recobraron a Maraquivir, Orán y sus castillos, con una breve noticia de estas Plazas, su situación, País y primera Conquista por el Rey Católico Don Fernando el V, dedicada al Príncipe nuestro Señor Don Fernando, por el doctor D. Pedro de la Cueva, del Consejo de S. M.... ${ }^{66}$.

Escrita por el auditor general de la expedición, Pedro de la Cueva, la narración presenta una descripción de Orán y sus fortificaciones, la historia natural del territorio y la historia de la ciudad. El folleto ofrece un relato de la empresa de 1732 comandada por Joseph Patiño y su exitosa recuperación de Orán, además incluye las listas de oficiales y "otros aventureros" que participaron en la expedición y de los que perecieron.

La "feliz victoria" suscitó otras Relaciones y hojas sueltas como la "Copia de carta que se refiere a la feliz victoria de la toma de la Plaza de Orán, Castillo de Mazalquivir y Montaña, que predomina la Plaza con todos los sucesos acaecidos en dicha expedición ${ }^{67}$. "Noticia cierta y Relación verdadera del felicísimo desembarco que ha tenido la nobilísima imperial como lealísima Armada Española de nuestro magnánimo monarca y señor don Felipe V, el animoso (que Dios guarde) comandada por el Excelentísimo Señor conde de Montemar a quien el Cielo conceda la absoluta victoria contra África y toda su Mahometana chusma» ${ }^{68}$. "Relación y curioso romance en que se declaran algunas noticias particulares que han sucedido en la toma y restauración de Orán, en este año de mil setecientos treinta y dos»"

65. RELACION de lo acaecido en la nauegacion de la armada, que se congrego en la babia de Alicante y de los gloriosos progressos del exercito del Rey en la Conquista o Restauración de la Plaza de Oran en Africa en los días 29 y 30 de Junio y 1 de Julio de este año de 1732. Vid. digitalizado en https://bivaldi.gva.es/es/catalogo_imagenes/grupo.do?path=1019266 [consultado 23 de enero de 2020].

66. Iconismos, Encomiasticon, o Verdadera Descripción y elogio de la Expedición de Africa. Impreso en Granada por José de la Puerta, 1732, 1. a y única edición.

67. BNE, Mss. 18.108.

68. BNE, VE (varios especiales), caja 641 (34)

69. Con licencia en Sevilla: imprenta castellana y latina de la viuda de Francisco Lorenzo de Hermosilla, en la calle de Vizcaínos, s. a. (BUS) Biblioteca Universitaria de Sevilla, 109-36 (50). 
La conquista de Orán tuvo asimismo su reflejo en la pintura. Una de las más representativas fue la secuencia visual de carácter propagandístico del pintor italiano Domenico Maria Sani, que en cuatro capítulos realza la hazaña de Felipe $V$. El primero de estos capítulos es el óleo en el que muestra las operaciones de embarque de la tropa y de avituallamiento en la flota antes de la partida desde Alicante. Las largas filas de soldados, por un lado, y de carros y bagajes, por otro, explican visualmente la excelente y espléndida organización llevada a cabo para la expedición de Orán. Al poder naval reflejado en el gran número de barcos dispuestos en la costa, muchos de ellos saetías destinadas al transporte, se suma el poder militar de las fuerzas de infantería que desde tierra se encaminan ordenadamente a realizar el embarque.

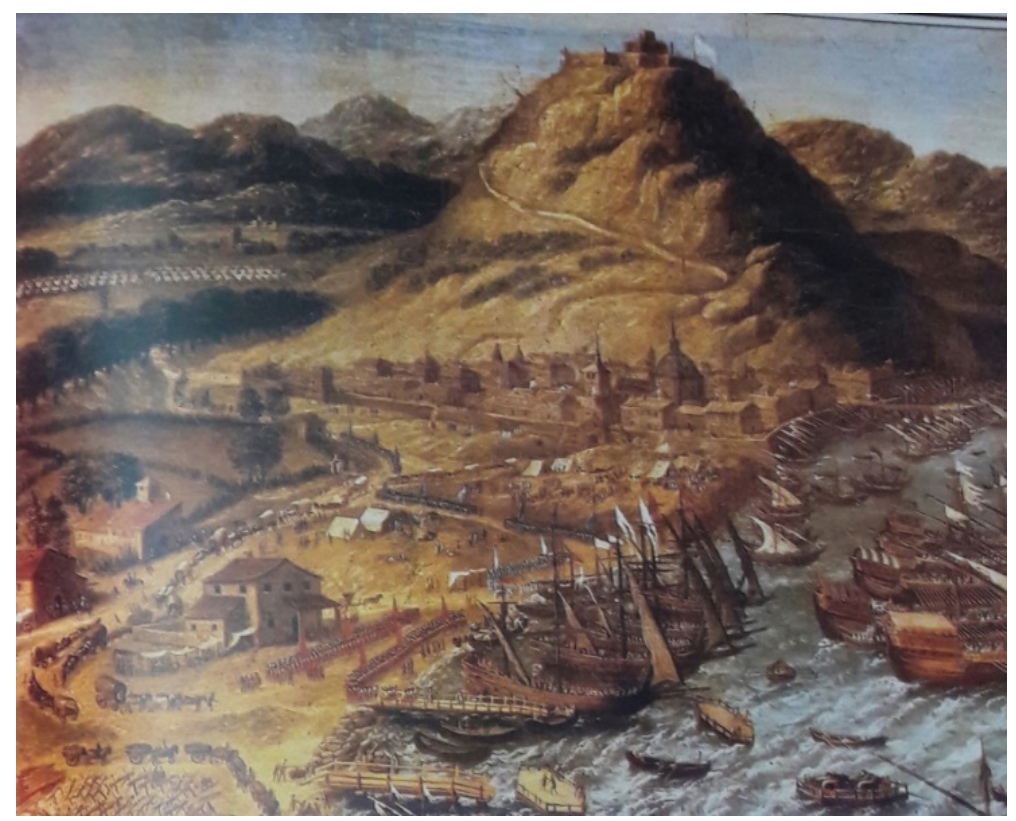

Fig. 13. La flota española parte a la conquista de Orán desde Alicante en 1732. Óleo de Domenico Maria Sani. 


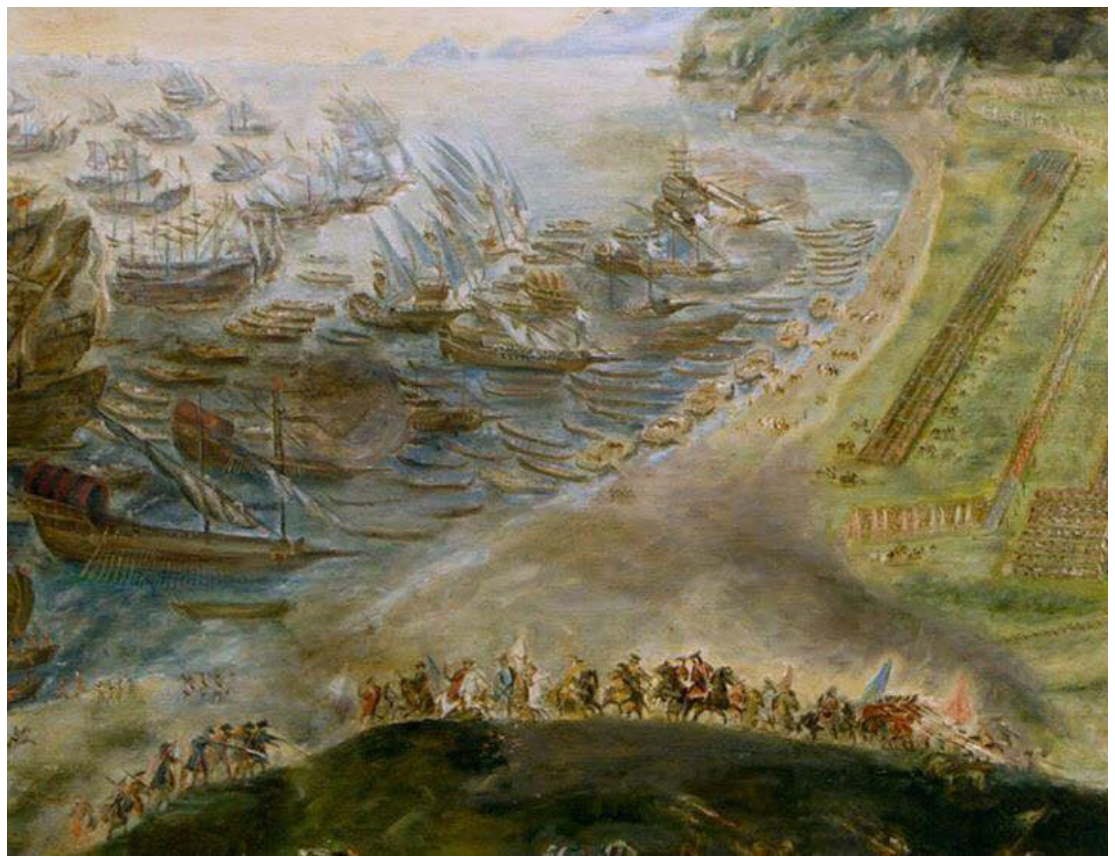

Fig. 14. La toma de Orán, 29 de junio de 1732. Óleo sobre lienzo, copia por Manuel Calderón realizada en 1994 de un original de Domenico Maria Sani (1690-1772), se encuentra en el Museo Naval de Madrid, Invt. 4798.

En la segunda secuencia se muestra el desembarco de las tropas en el lugar llamado Las Aguadas en Orán, llevado a cabo con orden y precisión en cumplimiento de las instrucciones que Francisco Cornejo dio en Alicante el 1 de junio de 1732. A la derecha, se observa una geografía muy accidentada que desciende suavemente hasta el mar; en el centro, la cabeza de playa atrincherada con el Regimiento de Asturias al mando de Sebastián de Eslava, en vanguardia. En primer plano, sobre una colina, los escuadrones de caballería española "a media brida" marchan contra los argelinos que se retiran precipitadamente. En segunda línea y en la orilla de la playa se ven los seis pontones varados, mientras numerosas embarcaciones se atracan a ellos para transferir a tierra a los hombres, las caballerías y pertrechos que transportan. En segundo plano, hacia el mar se encuentran las siete galeras destinadas a proteger el desembarco con sus fuegos. Por su popa, los navíos y demás embarcaciones de la escuadra proceden al barqueo de tropas hacia la playa. 


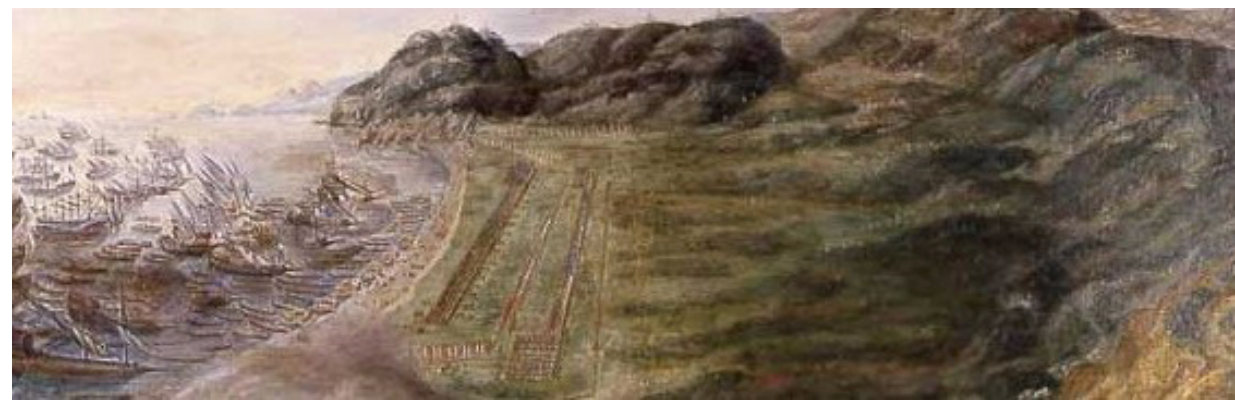

Fig. 15. La toma de Orán. Óleo sobre lienzo, copia por Manuel Calderón realizada en 1994 de un original de Domenico Maria Sani (1690-1772). Vista general.

Otro de los grabados sobre el desembarco de características propagandísticas es el de Zauber, K. cuyo mensaje trata de presentar no solo una victoria militar, sino también una cruzada religiosa. Con referencia al combate, el grabado sintetiza todas las fases de la operación a un mismo tiempo: desde el desembarco y traslado de los hombres a tierra, hasta la entrada victoriosa de las tropas al mando de Montemar en la fortificación de Orán el 1 de julio de 1732. En primer plano, aparece la figura a caballo en corveta del general en mando de la expedición con su bengala señalando a las tropas la dirección de la plaza a conquistar. El grabado no pretende la exactitud geográfica ni topográfica, sino expresar las ideas y concepciones propagandísticas que subyacen en él. De ahí que trate de realzar la misión de cruzada religiosa contra el islam, manifestada en el clérigo que a la cabeza de tropas va desde el cielo a Orán dirigiendo la operación de entrada en la plaza.

El 5 de julio, se cantó en Orán un solemne Te Deum para conmemorar la victoria $^{70}$. La noticia pronto llegó a España y se extendió al resto de Europa. El papa Clemente XII se alegró de la recuperación de las dos ciudades, dando las gracias y elogiando a Felipe V. En España, el rey mandó que se celebrara la victoria con diversos actos y fiestas en todas las ciudades del Reino ${ }^{71}$. Las celebraciones fueron tan sonadas en villas y ciudades que el portugués José Freire de Monterroy Mascarenhas se refirió a ellas en su escrito sobre la batalla y conquista de Orán de 1732:

70. SÁnchez Doncel, Gregorio. Presencia de España en Orán, 1509-1792. Salamanca: Instituto Superior de Estudios Teológicos San Ildefonso, 1991, p. 264.

71. López Gómez, Pedro. "Las relaciones de sucesos como tipología documental: la relación de las fiestas de Tui por la reconquista de Orán en 1732». Boletín de la ANABAD, 2018, 68, 3-4, pp. 164-207. 


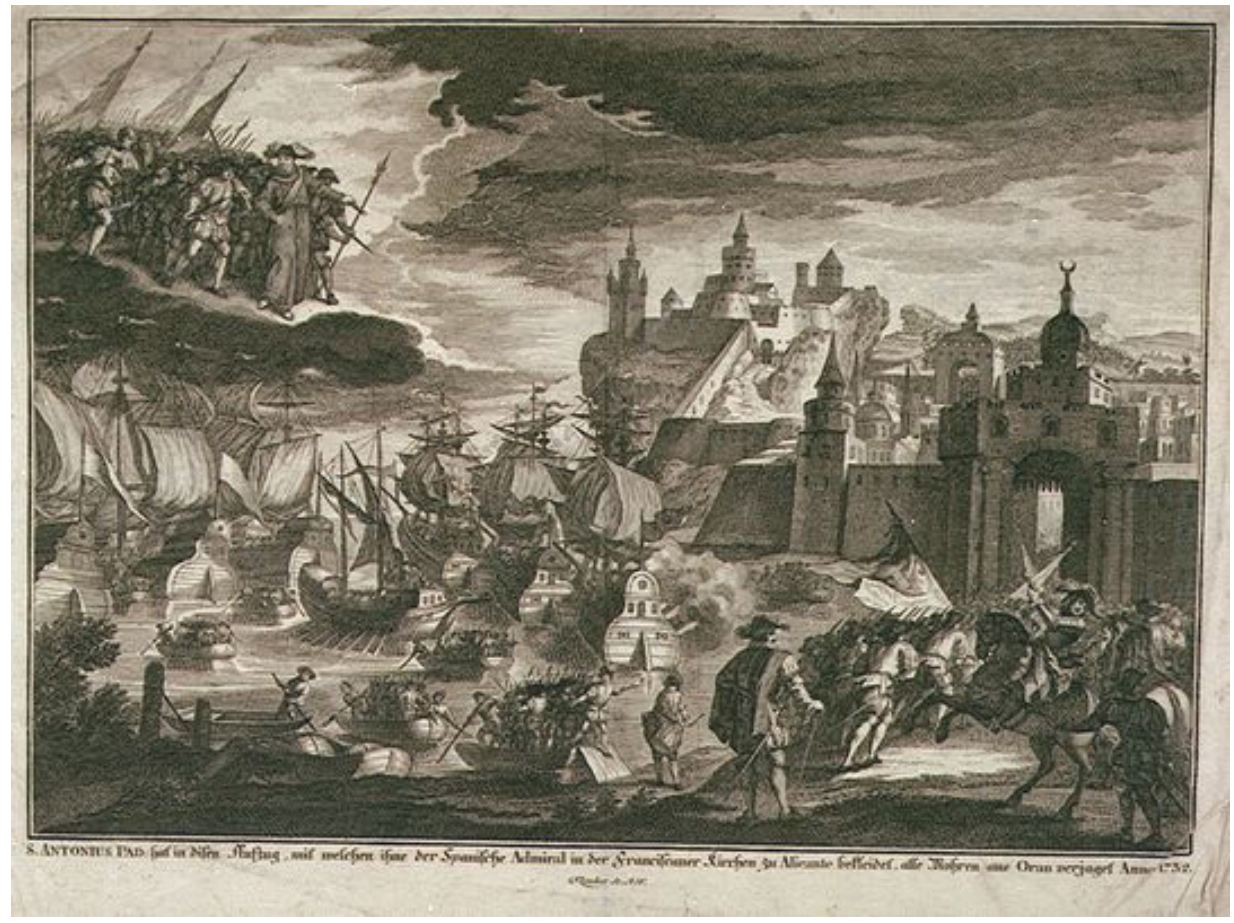

Fig. 16. Spanish attack on Oran 1732 by Zauber, K.

Haciéndose cuatro veces solemnemente el Te Deum por la felicidad del desembarco, por las circunstancias de la victoria, por la restauración de Orán y por la rendición de Mazalquivir con siete noches de luminarias generales, con una magnífica Procesión de acción de gracias, con máscaras de gala y con incesantes repiques de todas las campanas. Seis días se celebró también en Madrid extremosamente con procesiones, luminarias y repiques, máscaras y fuegos de artificio, compitiendo los moradores unos con otros sobre la mayoría de sus demostraciones y todas siendo grandes parecen corresponder con el tamaño de las empresas plausibles ${ }^{72}$.

72. Oran conquistado ou relacam histórica, em que se dà noticia desta Praça, da sua conquista, e da sua perda, e restauração, colbida de varios avisos [...]. Orán - Conquistada, o Relación histórica en que se da noticia de esta Plaza, de su conquista y su pérdida, y restauración, cosechada de varias advertencias y dedicada a Su Excelencia Sr. Domingos Capecelatro, Márquez de Capeceletro, bijo de sus Excelencias Duques de Siano, del Municipio de Su Majestad Católica en su Cámara de Indias y su embajador de la corte de Portugal, por José Freire de Monterroyo Mascarenhas. Lisboa Occidental, año de 1732. Contiene dos grabados, uno del plan de batalla y el otro de la explicación del plan. Lisboa: Oficina de Pedro Ferreira Impressor da Serenissima Rainha N. S., 1732, 4to., 20, (4) pp. 
Si en 1733 los reyes de España habían recuperado una gran parte el protagonismo perdido en el Mediterráneo, con la guerra de Sucesión de Polonia (1733-1738) y la guerra de Sucesión de Austria (1741-1748) lograron restablecer una gran parte de su antigua presencia en el escenario italiano. Entre las victorias españolas más sonadas en la opinión pública destacó la victoria de Guastalla del 19 de septiembre de 1734, cuyos primeros informes y relaciones circularon enseguida entre la población: "Relación de la victoria conseguida sobre los Imperiales por las tropas del Rey de Francia y las del Rey de Cerdeña en la Batalla que se dio cerca de Guastala el 19 de septiembre de $1734 »^{73}$. Otros papeles se prodigaron en el reñido y feroz combate, mostrando la gloriosa victoria alcanzada: "Verídica y cierta Noticia del reñido encuentro y batalla que en las cercanías de Guastala tuvieron el diecinueve del mes de Septiembre, las Armas y Tropas coligadas de Francia y Cerdeña, con el campo de los Imperiales.... ${ }^{74}$.

El sesgo propagandístico de estas obras se despliega sobre todo en las descripciones, muy periodísticas, sobre los graves aprietos y peligros sufridos ante un poderoso enemigo; el ejemplo más notorio fue el «Systema Político de la Europa dialogado entre un francés y un alemán» ${ }^{75}$. Esta obrita, centrada en el diálogo entre un alemán y un francés, expone dos visiones contrapuestas del Sistema político de Europa en 1734, y más concretamente se centra en las posibilidades de España en su política revisionista italiana: el alemán declara con duda y desdén que «el Infante Don Carlos es muy criatura para tanto empeño». El francés responde con aplomo en apoyo del joven Carlos de Borbón:

En el Infante Don Carlos se ha reconocido una vivacidad sobresaliente y con las demás partes de que deben componer un Soberano, le basta ser hijo de la Real Casa de Borbón y de la Heroína de nuestro siglo, y correrle no poca sangre por las venas del Gran Alejandro Farnesio, y por si esto no alcanzare, también le corre la bastante de ese vuestro Héroe el Príncipe Eugenio de Saboya, para con estas circunstancias poderle hacer rostro, y cumplir con las obligaciones del empleo de Generalísimo ${ }^{76}$.

En el curso de la guerra de Sucesión de Polonia, el triunfo realmente definitorio de la política exterior de Felipe V en Italia fue la batalla de Bitonto. Aquella victoria alcanzada después de nueve horas de combate por el todavía conde de

73. Madrid: Juan de Aritzia, 1734, 8 h.

74. Madrid: s. i., 1734, 2 h.

75. Systema politico de la Europa dialogado entre un francés, y un alemán sobre las disposiciones e interesses de los principes en la presente guerra, 1734, pp. 66-67.

[https://ucm.on.worldcat.org/oclc/555318707] [consultado el 10 de diciembre de 2019].

76. MAÑER, Salvador Joseph. Systema politico de la Europa: dialogado entre un frances y un aleman, sobre las disposiciones è interesses de los principes en la presente guerra / por Monsieur Margné; dedicado al... Señor D. Joseph Patiño, cavallero del insigne Orden del Toysòn de Oro, del Consejo de Estado de su Magestad, y su governador en el Real de Hacienda. En Madrid: hallaràse en la Libreria de Juan de Buytrago, en la Puerta del Sol, 1734. BNE, Sig. VE/306/39. 
Montemar y el joven príncipe Carlos desembocó en una explosión de relatos, relaciones, diarios, poemas, etc. La victoria de Bitonto significó la conquista del sur de Italia por las tropas españolas, lo que causó sensación en Europa, pero especialmente en Italia, donde los publicistas recogieron los hechos que cambiaron el dominio del sur peninsular. En el Giornale storico, Giuseppe Senatore evidenció su sesgo proborbónico en las extensas y exhaustivas noticias sobre las conquistas que "las Armas invencibles de España hicieron en Nápoles y Sicilia»" La victoria fue muy exaltada en la literatura de la época, como en el Poema heroyco: descripcion de la batalla de Bitonto en el Reyno de Napoles ${ }^{78}$. Asimismo, fue rememorada en imágenes, cuyo mejor ejemplo es el grabado en forma de abanico -modelo conocido como país o paisaje de abanico- en el que se recoge la Vitoriosa Batalla y Fuga de Alemanes en Bitonto ${ }^{79}$.

Los austriacos, en su huida de Bitonto, se pertrecharon en la plaza costera de Gaeta donde soportaron un asedio de casi cuatro meses conducido por la armada española, al mando del infante don Carlos, duque de Parma, y el ejército del duque de Montemar. La ciudad fue conquistada el 6 de agosto del 1734. La victoria del sitio de Gaeta tuvo amplia difusión a través de la Gaceta de Madrid ${ }^{80}$, fue conmemorada en el dibujo de la serie países en abanico, en cuya inscripción se lee: "Valerosa revista de Trincheras» del Real Infante de España Don Carlos Borbon en el Sitio de Gaeta año $1734^{81}$ y en el lienzo Asedio de una ciudad costera por el infante don Carlos de Borbón, una pintura de Giovanni Luigi Rocco que inmortalizó la conquista de Gaeta.

77. Giornale storico di quanto arvenne ne'due reami di Napoli e di Sicilia l'anno 1734 e 1735 nella conquista che ne fecero le invitte Armi di Spagna sotto la condatto del re Carlos Borbone, 1742, BNE, Sig. R/38064. Vid. Borreguero Beltrán, C. "El impacto de las noticias de guerra en la Corte Borbónica». En Martínez Millán, José; SÁnchez Belén, Juan Antonio y Rivero Rodríguez, Manuel (coords.). Del enfrentamiento a la amistad: influencias entre las monarquías de Francia y España en los siglos XVII y XVIII. Madrid: Polifemo, 2019, pp. 395-426.

78. En Madrid: a costa de Don Pedro Joseph Alonso y Padilla [...] se hallarà en su Imprenta, y Librería, 1734. BNE, Sig. VE/1051/38.

79. En realidad, existieron varias versiones del mismo autor: LA VEGA, Francisco (1734-1759). Vitoriosa Batalla y Fuga de Alemanes en Bitonto, bajo el comando del Exmo. Sr Conde de Montemar Genl de las Tropas de España en Italia, 1750. Sig. DIB/13/4/14. Biblioteca Digital Hispánica. LA VEGA, Francisco. País de abanico con la arquitectura efimera para las fiestas que celebraron la entrada en Nápoles del rey Carlos de Borbón, 1734. BNE, Sig. DIB/13/4/13. Dos versiones se conservan en el British Museum y una en la Hispanic Society de Nueva York.

80. "Se confirman las rendiciones de Gaeta y Pescara". Gaceta de Madrid, n. ${ }^{\circ}$ 36, de 7 de septiembre de 1734 , pp. 178 a 179

81. Firmado por "Fco. La Vega. Hispas. Bilbilitanus Inbv. e Deliniavit Roma", con la nota de haber sido "Miñado por Leonardo Egiarmon Flamenco". Génova, 19 de Agosto de 1734. Se encuentra en el British Museum (Prints \& Drawings 1891, 0713.606/7). http://www.bne.es/es/Actividades/Exposiciones/Exposiciones/Exposiciones2009/dibujos/visitavirtual/pdf/pdf_35.pdf [consultado 13.XII.2019]. 


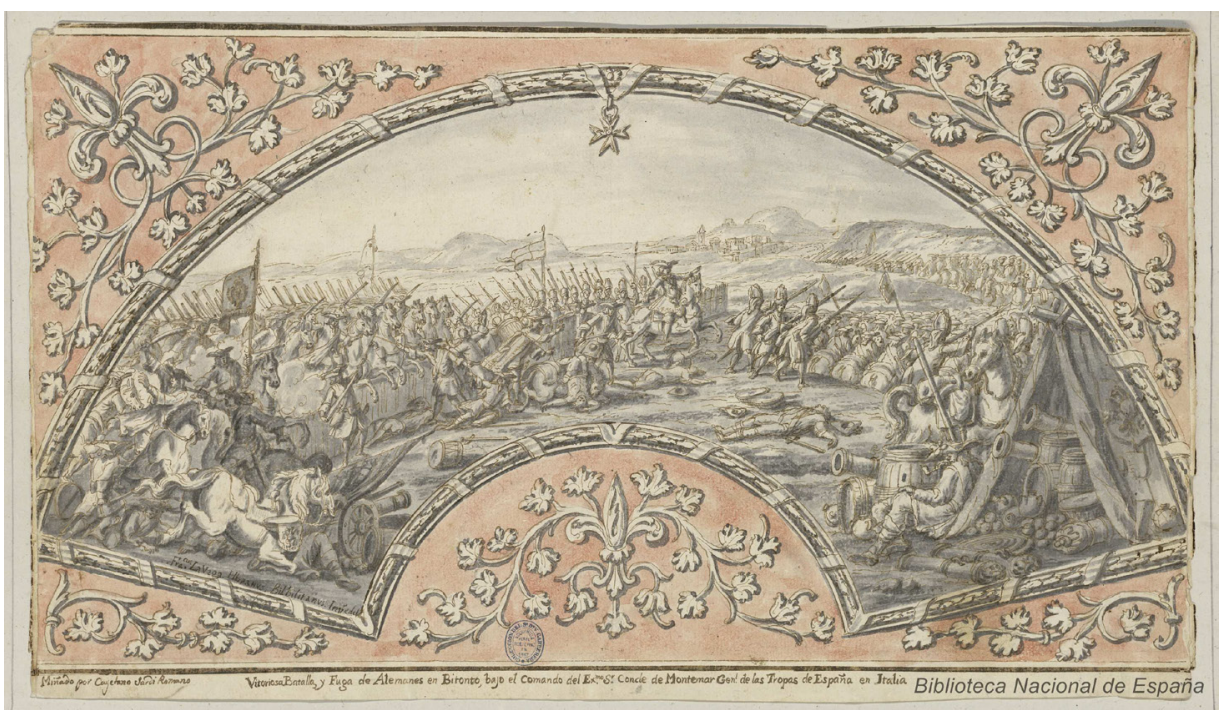

Fig. 17. Vitoriosa Batalla y Fuga de Alemanes en Bitonto, bajo el comando del Exmo. Sr. Conde de Montemar General de las Tropas de España en Italia. Dibujo sobre papel amarillento verjurado.

Al finalizar la guerra de Sucesión de Polonia, España había obtenido Nápoles y Sicilia, territorios que Felipe V cedió a su hijo Carlos reconociéndole como rey con el nombre de Carlos VII de Nápoles y V de Sicilia (1734-1759). Así se creó una rama menor de la dinastía borbónica, la de Borbón Don Sicilias, aunque fue en 1816 cuando ambos reinos se fusionaron constituyendo el reino de las Dos Sicilias.

\section{Sentimientos anglófobos y antihispanos en la GUERRA De la Oreja de JENKINS}

Cuando los ecos de la guerra de Sucesión de Polonia se habían acallado, en 1739 estalló el enfrentamiento marítimo y colonial entre Inglaterra y España que fue conocido como guerra del Asiento o de la Oreja de Jenkins (1739-1748). La contienda generó verdaderas campañas propagandísticas, antibritánica en España y antiespañola en Inglaterra. La operación antiespañola en Inglaterra estuvo servida a partir del incidente de 1732, cuando el guardacosta español Juan León Fandiño apresó el barco inglés Rebeca y tras confiscarlo cortó una oreja a su capitán, el contrabandista Robert Jenkins, al tiempo que le advertía osada y abruptamente: «Ve y dile a tu rey que lo mismo le haré si a lo mismo se atreve». Seis años después y en plena ruptura entre España e Inglaterra, Jenkins mostró ante la Cámara 
de los Comunes la oreja que había conservado en un frasco como prueba de la crueldad de los españoles. Nunca estuvo claro si aquel incidente fue real, pero su testimonio magnificado por la prensa conmovió a la opinión pública inglesa. Finalmente, el ministro Walpole se vio arrastrado a declarar la guerra a España el 30 de octubre de 1739, presionado por la oposición tory, la campaña propagandística basada en el testimonio de Jenkins en la Cámara y las amenazas de la compañía del Mar del Sur.

Evidentemente, los navíos españoles patrullaban en busca de mercantes ingleses sobre los que tenían derecho de visita y registro y podían confiscar la carga no permitida. Cada apresamiento provocaba airadas protestas y reclamaciones de Gran Bretaña, acusando a los guardacostas españoles de depredadores. Finalmente, el 10 de julio de 1739, Gran Bretaña aprobó una Declaración de Represalias, firmada por el rey, en la que se acusaba a España de las crueldades, injurias y graves pérdidas llevadas a cabo por los guardacostas en América.

Mientras que se han cometido en las Indias Occidentales y más allá, muchas, repetidas y muy injustas Depredaciones por los Guarda Costas españoles y también por navíos actuando bajo la comisión del rey de España o su Gobierno, [...] Su Majestad, tomando este injurioso proceder de la Corona de España en seria consideración y determinando tomar medidas necesarias para vindicar el honor de su Corona y procurar Reparación y Satisfacción a sus injuriados súbditos, se complace, tras la consulta de su Consejo Privado, ordenar que se hagan Represalias generales contra los barcos, bienes y súbditos del rey de España ${ }^{82}$.

En defensa de las acusaciones, el Gobierno de España redactó una réplica titulada Cotejo de la conducta de S. M. con la de el Rey británico, así en lo acaecido antes de la Convención de 14 de Enero de este año de 1739 como en lo obrado después, hasta la publicación de Represalias y declaración de Guerra. Con esta declaración, la monarquía española pretendió:

descubrir a la Europa la indiferencia que media entre una y otra razón, para que examinada por el juicio imparcial de los que apetecen la quietud publica, no se atribuya maliciosa o ignorantemente a la Armas Españolas, ni el origen de este rompimiento, ni los lastimosos irremediables efectos que amenazan con errada política a la Christiandad ${ }^{83}$.

Asimismo, el Cotejo dio visibilidad a las exageraciones de Gran Bretaña con referencia a la intervención de los guardacostas en América, la irregular conducta de sus buques mercantes y la auténtica actuación del Gobierno de España mostrándose víctima de Inglaterra, cuyos excesos -verdaderas piraterías, persecuciones y atrocidades en América- había soportado y acallado durante mucho tiempo.

82. Whitehall, the 10th Day of July 1739. Vid. The London Gazette, From Saturday July 7 to Tuesday July 10, 1739. AGS, EST., leg. 6909, 7.

83. Cotejo de la conducta de S. M con la de el Rey Británico. AGS, EST., leg. 6909, 1. 
Para la difusión del documento, Felipe V ordenó la impresión y encuadernación de 750 folletos que envió a todos los ministros españoles en Europa. La resonancia del Cotejo español encontró en Italia un terreno favorable y un gran aliado en el padre dominico Salvador Ascanio, agente de Felipe V en Florencia, que vio necesario traducirlo al italiano con el título CONFRONTO DELLA CONDOTA DEL RE CATOLICO CON QUELLA DEL RE BRITANICO negl' incidente ocorsi avanti e dopo la Convenzione de 14 Genero 1739 fino alla publicacione delle Rapresaglie e Dichiaraziones di Guerra. Su publicación en Roma y Florencia facilitó "satisfacer la curiosidad de este Público y el de otras Ciudades de Italia, donde se ha leído y se lee con tanto gusto, cuando es grande el disgusto de Yngleses y de sus Parciales ${ }^{84}$.

En Florencia, un acontecimiento anual -el cumpleaños del rey de España-servía para forjar los sentimientos de afinidad y sintonía con la Monarquía española:

En esta vigilia del felicísimo cumpleaños del Rey, Dios le guarde, concurren los pobres de la Ciudad y de sus contornos a las Puertas de este Convento y en sus claustros, en número tan considerable para recibir el Pan, llamado a gritos Pan del Rey de España, que me he visto precisado a dispensarlo hoy y prevenir otra cantidad para mañana, logrando la satisfacción que tendría VE de oír hablar los corazones de esta pobre gente, implorando a nuestra Real Familia las Divinas Bendiciones, que imploran públicamente ${ }^{85}$.

Tras la declaración de guerra, los británicos enviaron una escuadra al Caribe y otra al Pacífico con el objetivo final de perjudicar los intereses comerciales del Imperio español y de aniquilar su monopolio comercial. La escuadra del Caribe, al mando de Edward Vernon, hostigó varios puertos españoles hasta que el 21 de noviembre de 1739 tomó Portobelo con solo seis barcos. La facilidad de aquella conquista le animó a atacar también Cartagena de Indias, la llave de la América española. Entre los meses de marzo y mayo de 1741, a pesar de los esfuerzos por hacerse con el puerto español, fracasó en su intento gracias al genio militar de Blas de Lezo, teniente general de la Armada.

La escuadra británica del Pacífico, al mando de George Anson, realizó una odisea victoriosa que causó gran sensación en Inglaterra. A los navíos ingleses les fue fácil capturar el fuerte de Paita en Perú y el galeón de Manila para regresar triunfantes a Londres por el cabo de Buena Esperanza en 1744. La propaganda británica se encargó de diseñar su hazaña como una operación memorable.

El análisis de tres grabados es revelador de la campaña propagandística antiespañola que se difundió en Inglaterra. La historia de Jenkins fue reactivada en los grabados caricaturescos que criticaban las acciones humillantes hacia Inglaterra causadas por los españoles.

84. Carta de Ascanio al Marqués de Villarias. Florencia 5 de febrero, 1740. AGS, EST., leg. 7780.

85. Carta de Fray Salvador Ascanio al Marqués de Villarias Florencia, 18 de diciembre 1739. AGS, EST., leg. 7780. 


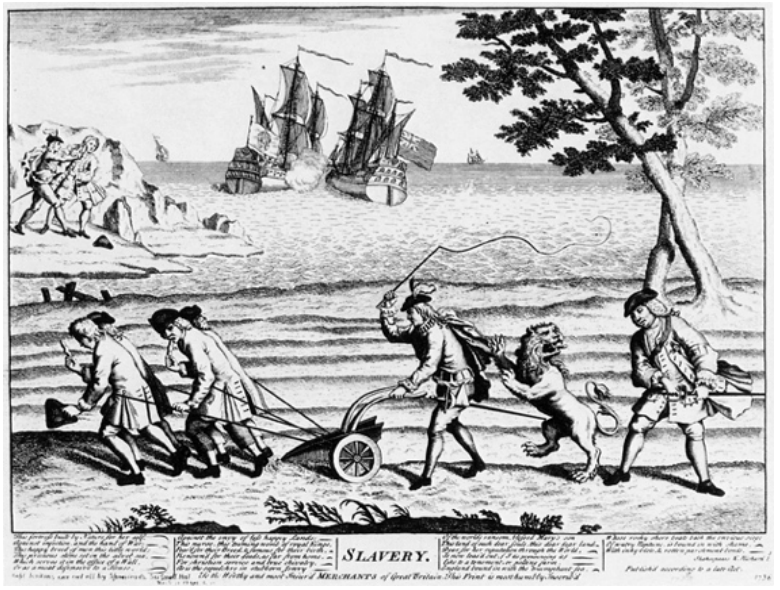

Fig. 18. English Satirical Print - Slavery, 1738.

En el grabado anónimo, titulado Esclavitud y fechado en 1738, Inglaterra ataca el sistema colonial español. En primer plano, el león inglés agrede a un labrador (el Gobierno de España) que conduce un arado tirado por esclavos, (el sistema colonial español). En un segundo plano se reproduce la afrenta del guardacosta español Juan León Fandiño cortando la oreja a George Jenkins. Finalmente, en un tercer plano, un barco británico, identificado por su bandera, se encuentra en pleno combate contra uno español.

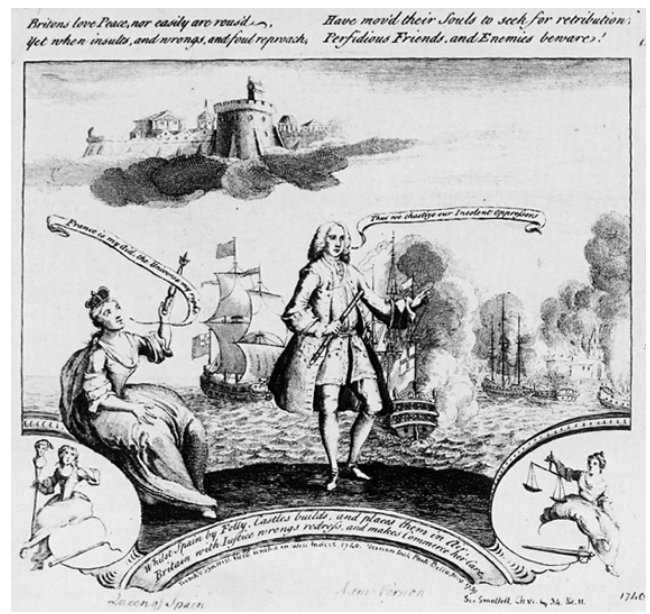

Fig. 19. English Satirical Print - Spain builds castles in the air, Britain makes commerce her care, 1740. 
Un grabado particularmente irónico y mordaz contra España publicado en 1740 es el titulado Spain builds castles in the air, Britain makes commerce her care in the War of Jenkins'Ear. El dibujo es al mismo tiempo una glorificación del almirante Vernon, quien aparece de pie con su bastón de mando como victorioso comandante de la escuadra del Caribe, tras la conquista de Portobelo el 21 de noviembre de 1739. A su derecha, la reina de España (Isabel de Farnesio) aparece sentada comentando para deshonra de la Corona española: "Francia es mi ayuda, el Universo mi reino». En el segundo plano, la desafiante escuadra de Vernon está atacando Portobelo sin dificultades. Finalmente, en un tercer plano, se reproduce un castillo en el aire. Por si quedaran dudas, en la inscripción se dice: "Whilst Spain by Folly Castles builds and places them in air, Britain with justice wrongs redress, and makes Commerce heir care».

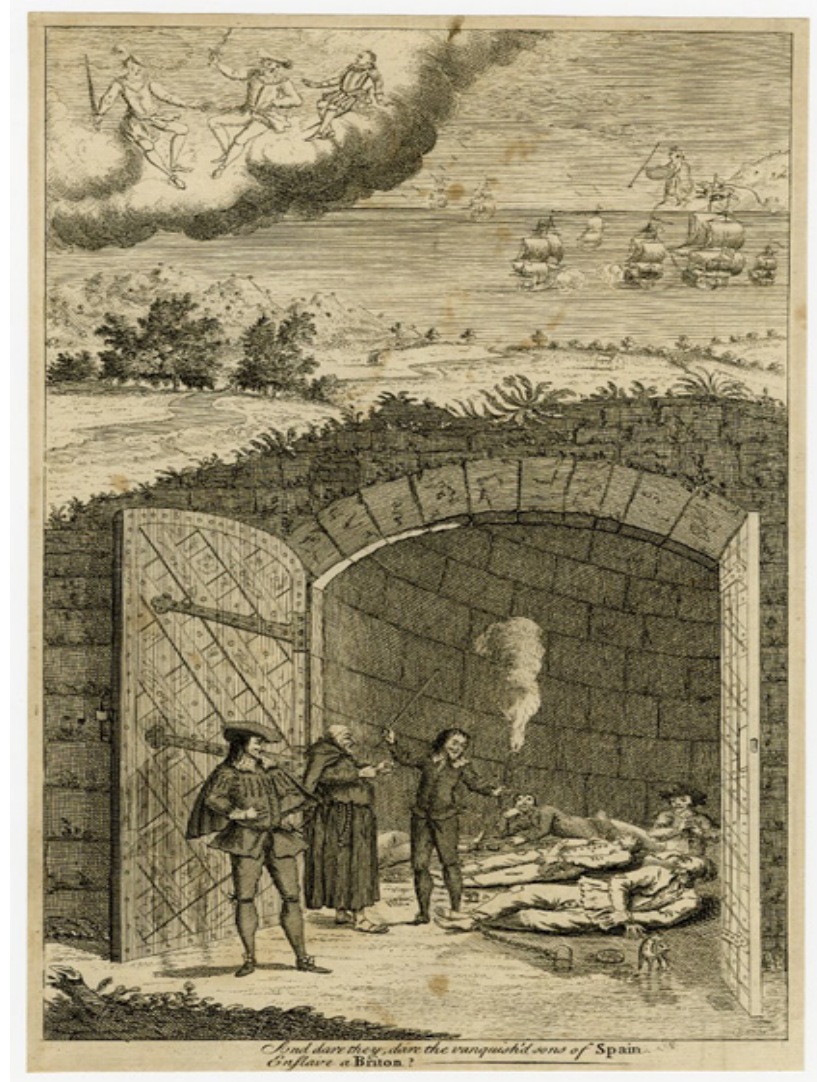

Fig. 20. English Satirical Print: Frontispiece to The Voice of Liberty; or, a British Philippic, 16.V.1738. Caricature. British Museum. 
El último grabado es una sátira apelando al Gobierno británico a declarar la guerra a España. Se trata de un dibujo en el frontispicio de un folleto en verso, de doce páginas, titulado $\mathrm{La}$ Voz de la Libertad. El anónimo autor presenta a cinco marineros británicos capturados por los españoles que yacen encadenados en el suelo de una prisión subterránea. Los españoles, que parecen espadachines del siglo XVII, entran en la prisión con una antorcha acompañados de un fraile. En segundo plano, los navíos españoles están disparando contra los británicos, que buscan hacer justicia y consumar la venganza siguiendo el derrotero de Thomas Cavendish, Walter Raleigh y Robert Blake, comandantes navales distinguidos citados en el poema, cuyos espíritus aparecen en los cielos. En un tercer plano Britannia y su león se paran en una orilla distante. El grabado fue publicado el 16 de mayo de 1738 con el objetivo de apelar a la guerra contra la Monarquía española, como expresa su inscripción: «And dare they, dare the vanquish'd sons of Spain Enslave a Briton» ("Y atrévete, desafía a los hijos vencidos de España que esclavizan al británico»).

\section{CONClusiones}

A partir de 1742, la guerra del Asiento se transformó en un episodio más de la guerra de Sucesión Austriaca (1741-1748), cuyo resultado en el teatro americano finalizaría con la derrota británica y el retorno al statu quo previo a la guerra.

Cuando Felipe V murió en julio de 1746, quedaba atrás medio siglo de reivindicaciones territoriales y de esfuerzos por la recuperación de la influencia y reputación de la Monarquía española. El monarca había logrado asentar a su hijo Carlos como rey de Nápoles y Sicilia y a su hijo Felipe como duque de Parma, Piacenza y Guastalla, por la paz de Aquisgrán de 1748. Al mismo tiempo, había conseguido recuperar su presencia activa en el Mediterráneo y mantener más o menos incólume su imperio colonial en América.

Para estas empresas, Felipe V había emprendido la reconstrucción de sus fuerzas armadas después de la guerra de Sucesión española y había logrado una magnífica preparación, organización y despliegue militar. Al mismo tiempo, había propiciado el impulso y desarrollo de campañas propagandísticas, de cuya utilidad era plenamente consciente, para granjearse una opinión pública favorable a sus proyectos y cercenar las críticas y afrentas del enemigo. Hubo, sin duda, en todos los enfrentamientos de su reinado denominadores comunes tanto en las estrategias y recursos propagandísticos como en los mensajes utilizados. En primer lugar, en la guerra de Sucesión y en la guerra de la Cuádruple Alianza, se utilizó el discurso de carácter oficial para justificar las empresas bélicas. Los manifiestos o proclamas expusieron las razones de la intervención en la guerra y, en este último caso, de la invasión de Cerdeña y Sicilia. También en la guerra del Asiento, el monarca optó por publicar una declaración en la que presentó una imagen de España víctima de las acusaciones de Inglaterra. 
Asimismo, la Monarquía trató de influir enérgicamente en la opinión pública a favor de sus objetivos militares mediante los instrumentos publicitarios disponibles en la época. En todas las contiendas, se utilizaron la prensa oficial, las relaciones de batallas impresas bajo control de la censura y una pléyade de escritores en consonancia y al servicio de la Monarquía.

Con todo, el discurso oficial alcanzó su cenit en las celebraciones por los triunfos bélicos. Algunas victorias decisivas fueron muy festejadas por la Monarquía, como la de Almansa en la guerra de Sucesión española o la de Bitonto en la guerra de Sucesión de Polonia, sin olvidar la liberación de Ceuta o la toma de Orán. Estas "guerras de papel» procuraron sobre todo justificar las empresas bélicas, influir enérgicamente en la opinión pública a favor de los objetivos militares, estimular las celebraciones de las victorias y disminuir el impacto de las derrotas, todo con el fin de lograr el mayor rédito posible de las acciones bélicas de la Monarquía. Así, pues, el monarca apostó tanto por las armas de fuego como por las armas de papel, sin olvidar las armas visuales - pinturas, grabados, litografías y estampas-, especialmente de las victorias.

La propaganda en la guerra de Sucesión tuvo una vertiente propia en la publicística religiosa, donde algunos eclesiásticos se sirvieron del púlpito para formar opinión. También en las jornadas del norte de África se adoptaron recursos de índole religiosa contra el musulmán.

Pero la propaganda tuvo otra vertiente no menos eficaz en la publicística surgida de forma espontánea en versos, poemas, relaciones de batallas, noticias de gacetas, sátiras, opúsculos, obras literarias, y todo tipo de "papeles echadizos» de amplia resonancia que afluyeron por las calles de las principales ciudades de Europa y cruzaron el Atlántico para eclosionar también en América.

\section{Bibliografía}

Alabrús Iglesias, Rosa María. "El eco de la batalla de Almansa en la publicística». Revista de Historia Moderna: Anales de la Universidad de Alicante, 2007, 25, pp. 113-128.

ALABRús Iglesias, Rosa María. "La trayectoria de la opinión política en la España moderna». Obradoiro de Historia Moderna, 2011, 20, pp. 337-354.

AlBAREDA, Joaquim. La guerra de Sucesión de España, 1700-1714. Barcelona: Crítica, 2010. Alonso Aguilera, Miguel Ángel. La conquista y el dominio español de Cerdeña (1717-1720): introducción a la política española en el Mediterráneo posterior a la Paz de Utrecht. Valladolid: Universidad de Valladolid, 1977.

BAUdot, María. «El regreso de Felipe V a Italia después de la Guerra de Sucesión». RUHM, 2016, 5/10, pp. 67-88.

BLACK, Jeremy. The English Press in the Eighteenth Century. Nueva York: Routledge Revivals, 2011 (1. ${ }^{a}$ ed. 1987).

Boeri, Giancarlo; Giacome Piana, Paolo y Mirecki Quintero, José Luis de. "La batalla de Francavilla». Desperta Ferro: Historia Moderna, 2019, 39, pp. 44-49.

Borreguero Beltrán, C. «Imagen y propaganda de guerra en el conflicto sucesorio (1700-1713)». Manuscrits, 2003, 21, pp. 95-132. 
Borreguero Beltrán, C. «El impacto de las noticias de guerra en la Corte Borbónica». En Martínez Millán, José; SÁnchez Belén, Juan Antonio y Rivero Rodríguez, Manuel (coords.). Del enfrentamiento a la amistad: influencias entre las monarquías de Francia y España en los siglos XVII y XVIII. Madrid: Polifemo, 2019, pp. 395-426.

BouzA, Fernando. «Sin armas de noticias. Medios de cultura escrita, público y poder monárquico a comienzos del siglo XVIII». En La Real Biblioteca Pública, 1711-1760, de Felipe V a Fernando VI. Madrid: Biblioteca Nacional de Madrid, 2004, pp. 33-47.

CAMPOS Y FERNÁNDEZ DE SEVILla, Javier. «La guerra de Sucesión Española vista a través de la historia general de la orden de San Jerónimo». Cuadernos de Investigación Histórica, 2007, 24, pp. 57-98.

Díez Revenga, Francisco Javier. "La Gazeta de Murcia (1706): un periódico murciano de la Guerra de Sucesión». En Luis Belluga y Moncada: la dignidad de la púrpura. Murcia: Fundación CajaMurcia, 2006, pp. 203-219.

EGIDO López, Teófanes. «La otra prensa del Antiguo Régimen y la oposición al poder». En Del Periódico a la Sociedad de Información, vol. I. Madrid: Sociedad Estatal España Nuevo Milenio, 2002, pp. 93-110.

EGIDO LÓPEZ, Teófanes. Opinión pública y oposición al poder en la España del siglo XVIII (1713-1759). Valladolid: Secretariado de Publicaciones e Intercambio Editorial, 2002.

Ellul, Jacques. Historia de la propaganda. París: Presses Universitaires de France, 1967.

FÉ CANTÓ, Luis F. «El desembarco en Orán en 1732». RUHM, 5/10/, 2016, pp. 89-110.

GonZÁlez Cruz, David. «La "demonización" del enemigo en el discurso bélico de la Guerra de Sucesión Española». En Contreras Contreras, J.; Alvar Ezquerra, A. y Ruiz RoDRíguez, J. I. (coords.). Política y cultura en la época moderna: (cambios dinásticos, milenarismos, mesianismos y utopias). Alcalá de Henares: Servicio de Publicaciones de la Universidad de Alcalá de Henares, 2004, pp. 217-234.

GonZÁlez CRuz, David. Propaganda e información en tiempos de guerra: España y América (1700-1714). Madrid: Sílex, 2009.

GonZÁlez CruZ, David. "Propaganda y estrategias de legitimación de la Sucesión en los dominios de la Monarquía Hispánica (1700-1714)». En BERnARDo ARES, José Manuel (coord.). La sucesión de la Monarquía Hispánica 1665-1725. Córdoba: Universidad de Córdoba y Cajasur, 2009, pp. 167-208.

GonZÁlez CruZ, David. «Propaganda y fuentes de información en la prensa periódica de la América Hispana durante las guerras del siglo XVIII. Obradoiro de Historia Moderna, pp. 355-384.

GONZÁlEZ CRUZ, David. «Espacios y territorio en la propaganda y en los discursos durante los conflictos bélicos: la Guerra de Sucesión en España y América». e-Spania. Revue interdisciplinaire d'études hispaniques médiévales et modernes. [En ligne], 2012, 14, mis en ligne le 16 janvier 2013.

GONZÁlez CruZ, David. "Los discursos religiosos propagandísticos en la estrategia de la Guerra de Sucesión». Libros de la Corte.es, 2013, 7, pp. 156-158.

GonZÁlez MezQuita, María Luz. "Alberoni y la revisión del sistema de Utrecht: buscar la neutralidad y conquistar la opinión». En Sociedad, cultura y política en el Antiguo Régimen: Prácticas y representaciones en la Monarquía de España. Mar del Plata: Ed. Biblos, 2019, pp. 251-276.

LEÓN SANZ, Virginia. «El conde Amor de Soria: Una imagen austracista de Europa después de la paz de Utrecht». En Guimerá, A. y Peralta Ruiz, V. (coords.). El equilibrio de los 
Imperios: de Utrecht a Trafalgar. Madrid: Fundación Española de Historia Moderna, 2005, pp. 133-154.

López CAMPILlo, Rosa María. Imagen y propaganda política en la guerra de Sucesión Española: Daniel Defoe al servicio del gobierno de Ana Estuardo. Madrid: Sílex, 2014.

López Campillo, Rosa María. «Daniel Defoe, propagandista político al servicio de los intereses comerciales británicos durante la guerra de Sucesión Española (1702-1714)». En La guerra de Sucesión Española y la opinión pública hispano-británica. Madrid: Sílex, 2014, pp. 31-54.

López CAMpillo, R. M. y Losa Serrano, P. "La propaganda política whig en la Guerra de Sucesión Española. George Ridpath y las campañas peninsulares de 1710». Ensayos: Revista de la Facultad de Educación de Albacete, 2010, 25, pp. 211-232.

LóPEz Gómez, Pedro. «Las relaciones de sucesos como tipología documental: la relación de las fiestas de Tui por la reconquista de Orán en 1732». Boletín de la ANABAD, 2018, 68, 3-4, pp. 164-207.

LÓPEZ-CORDÓN CORTEZO, M. ${ }^{a}$ V. «La instauración de una dinastía: propaganda, poder y familia en época de los primeros Borbones». En La Real Biblioteca Pública, 1711-1760, de Felipe V a Fernando VI. Madrid: Biblioteca Nacional de Madrid, 2004, pp. 17-32.

LÓPEZ-CORDÓN CORTEZO, M. ${ }^{a}$ V. «Defender a un rey, convencer a Europa: razones e imágenes de la propaganda castellana durante la contienda sucesoria». En GARCía GONZÁLEZ, Francisco (coord.). La guerra de sucesión en España y la batalla de Almansa: Europa en la encrucijada. Madrid: Sílex, 2009, pp. 285-306.

LOSA SERRAnO, Pedro. "La propaganda Whig sobre las batallas de Málaga, Almansa y Brihuega durante la Guerra de Sucesión. En La guerra de Sucesión española y la opinión pública bispano-británica. Madrid: Sílex, 2014, pp. 69-98.

LOSA SERRANO, Pedro. "La rivalidad propagandística entre Whigs y Tories sobre la batalla naval de Málaga en 1704». En La guerra de Sucesión Española y la opinión pública hispano-británica. Madrid: Sílex, 2014, pp. 55-68.

Maqueda Abreu, Consuelo. «En torno al Decreto de Nueva Planta de Cerdeña, 1717-1720». Revista de Derecho UNED, 1, 2006, pp. 425-468.

MARINO, Nancy F. "The "Romance de Carlos V" and the Emperor's Imperial propaganda machine». Caliope, 2014, 19, 2, pp. 35-49.

Martínez Gil, Fernando. «Los sermones como cauce de propaganda política: la Guerra de Sucesión". Obradoiro de Historia Moderna, 2011, 20, pp. 303-336.

Morales, Nicolás y Quiles García, Fernando (coords.). Sevilla y corte: las artes y el lustro real (1729-1733). Madrid: Casa de Velázquez, 2010.

Pérez Picazo, M. Teresa. La publicística española en la Guerra de Sucesión. Madrid: Consejo Superior de Investigaciones Científicas, 1966.

RIEss, Marta. Das wort von der Kanzel. Kirchliche Propaganda während des Spanischen Erbfolgekrieges. Sarrebruck: VDM-Verlag Dr. Müller, 2008.

SAllés Villaseca, Nuria. Giulio Alberoni y la dirección de la política exterior española después de los tratados de Utrecht (1715-1719). Tesis doctoral. Barcelona: Universitat Pompeu Fabra, 2016.

SÁnchez Doncel, Gregorio. Presencia de España en Orán, 1509-1792. Salamanca: Instituto Superior de Estudios Teológicos San Ildefonso, 1991.

SÁNCHEZ RUIZ, Raquel. Estrategias persuasivas y de manipulación ideológica en el discurso político: George Ridpath y la opinión pública inglesa durante la guerra de Sucesión Española. (1710-1713). Tesis doctoral, Universidad de Castilla-La Mancha, 2014. 
SEgura SimÓ, Ricardo. «La pintura y el grabado en la Guerra de Sucesión: la batalla de Almansa». En Santamaría Conde, Alfonso; García-Saúco Beléndez, luis G. y Sánchez FERRER, José (coords.). II Congreso de Historia de Albacete. Albacete: Instituto de Estudios Albacetenses Don Juan Manuel, 2002, 3, pp. 327-341.

STORRS, Christopher. The Spanish Resurgence, 1713-1748. New Haven, Connecticut: Yale University Press, 2016. 
